\title{
KULEUVEN
}

Leuven Centre

for Global

Governance Studies

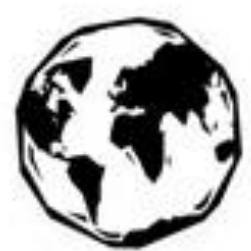

Institute for

International Law

Working Paper No. 157 - April 2015

\section{Assessing the Contribution OF THE INTERNATIONAL JUDICIARY TO THE RULE OF LAW: ELEMENTS OF A ROADMAP}

Geert De Baere Anna-Luise Chané Jan Wouters

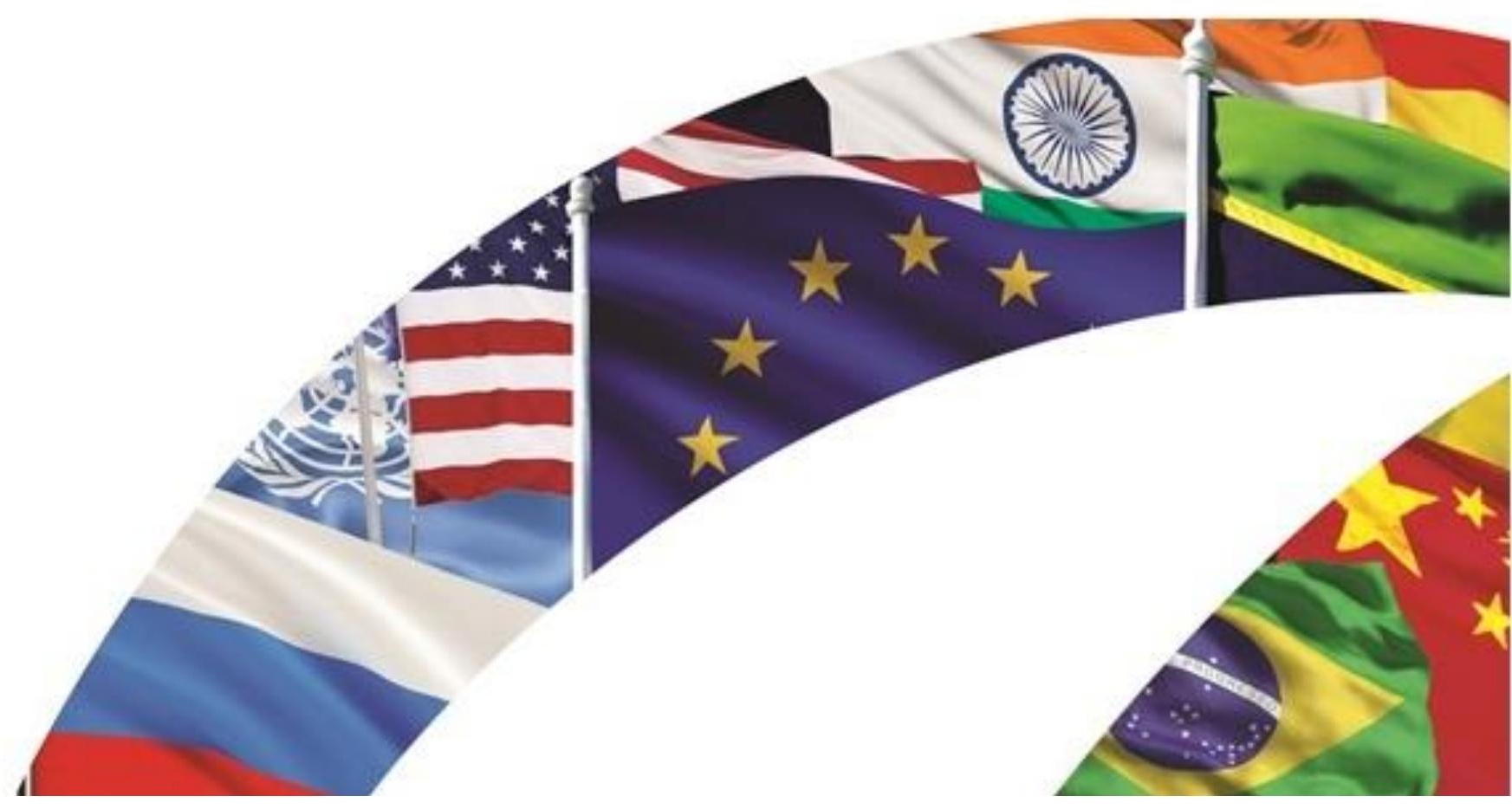




\title{
ASSESSING THE CONTRIBUTION OF THE INTERNATIONAL JUDICIARY TO THE RULE OF LAW: ELEMENTS OF A ROADMAP
}

\author{
Geert De Baere, Anna-Luise Chané and Jan Wouters
}

\begin{abstract}
This paper develops an analytical framework to assess the contribution of international and supranational courts and tribunals to the rule of law at international, regional, and domestic levels. After a brief historical overview of the rise of international adjudication, it clarifies the distinction between supranational and international bodies and explores possible interpretations of the concept of the rule of law. Subsequently, the paper places the international judiciary in its political context and analyses the institutional safeguards of the courts' independence and impartiality. Finally, the authors provide a preliminary comparative analysis of the many ways in which international courts may arguably strengthen the rule of law and concludes by taking a closer look at the remaining challenges that the international judiciary faces today.
\end{abstract}

\section{KEYWORDS}

Appellate Body of the World Trade Organization, Court of Justice of the European Union, European Court of Human Rights, Independence and Impartiality, International Court of Justice, International Criminal Court, International Criminal Tribunal for the Former Yugoslavia, International Tribunal for the Law of the Sea, Iran-United States Claims Tribunal, Judicial functions, Rule of Law, Special Tribunal for Lebanon, Supranationalism

This paper is an adapted version of the introductory chapter to the book 'The Contribution of International and Supranational Courts to the Rule of Law', Geert de Baere and Jan Wouters (eds.), Edward Elgar Publishing, forthcoming in 2015. Many thanks to Mr Nicolas Hachez for his helpful comments.

\section{AUTHORS}

Geert De Baere is Associate Professor of EU and International Law at the Institute for European Law and the Leuven Centre for Global Governance Studies, KU Leuven.

Anna-Luise Chané is a Doctoral Research Fellow at the Leuven Centre for Global Governance Studies Institute for International Law, KU Leuven.

Jan Wouters is Jean Monnet Chair ad personam EU and Global Governance, Full Professor of International Law and International Organizations and Director of the Leuven Centre for Global Governance Studies and the Institute for International Law (KU Leuven).

\section{ADDRESS FOR CORRESPONDENCE}

Geert.Debaere@law.kuleuven.be

AnnaLuise.Chane@ggs.kuleuven.be

Jan.Wouters@ggs.kuleuven.be

(C) 2015 by Geert De Baere, Anna-Luise Chané and Jan Wouters. All rights reserved. No portion of this paper may be reproduced without permission of the authors. Working papers are research materials circulated by their authors for purposes of information and critical discussion. They have not necessarily undergone formal peer review. 


\section{TABLE OF CONTENT}

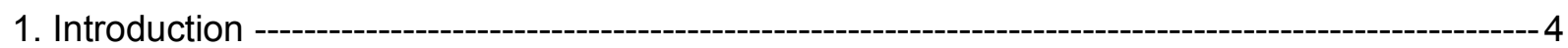

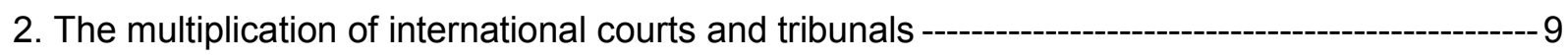

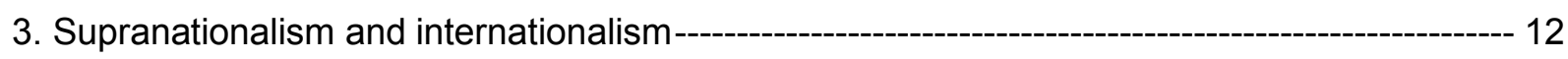

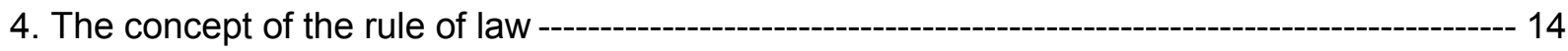

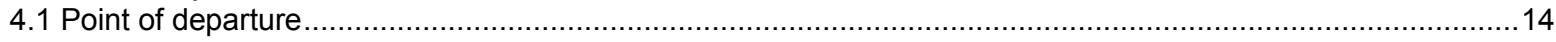

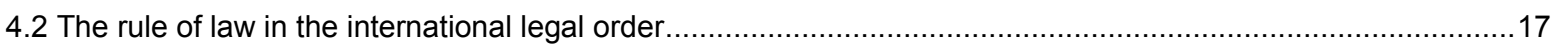

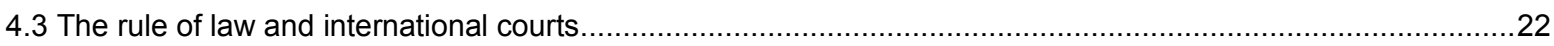

5. Independence and impartiality --

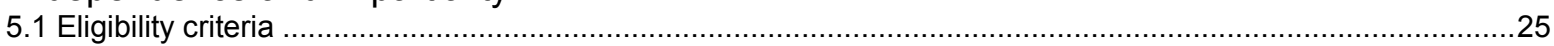

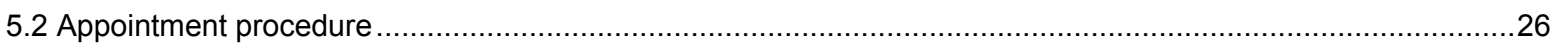

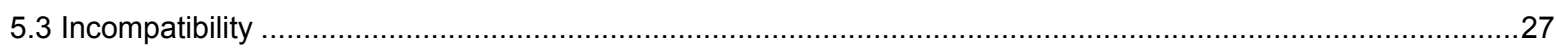

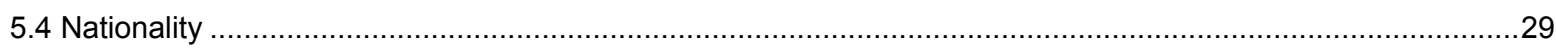

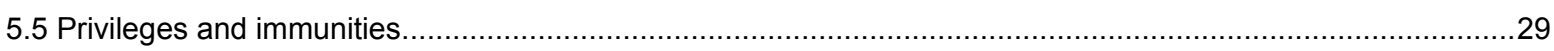

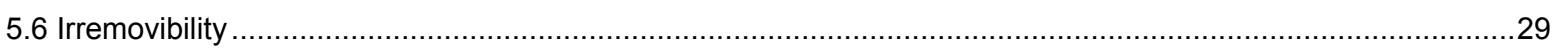

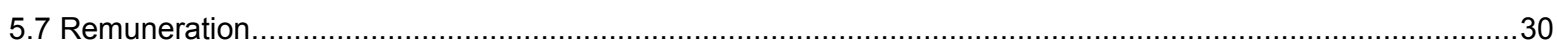

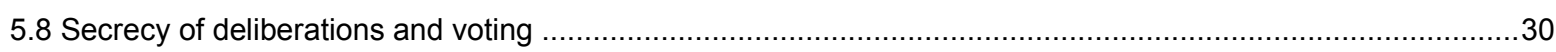

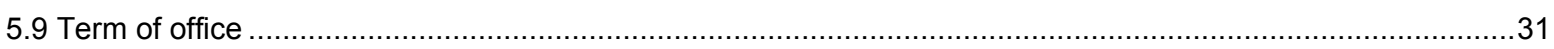

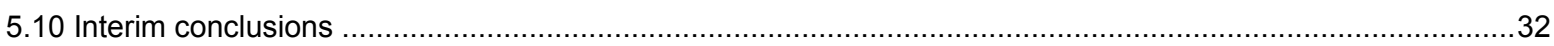

6. An overview of the contribution of international and supranational courts to the rule of law - 33

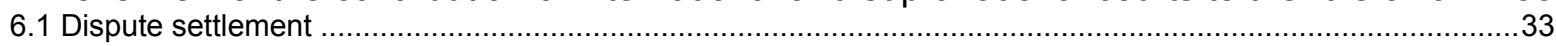

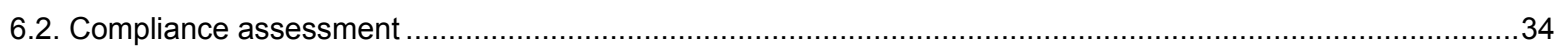

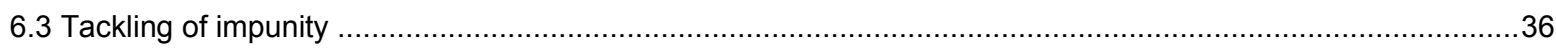

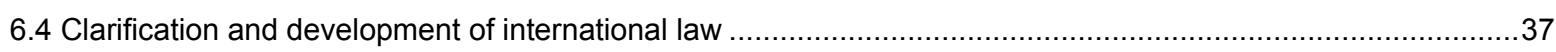

7. Conclusion -- 40 


\title{
ASSESSING THE CONTRIBUTION OF THE INTERNATIONAL JUDICIARY TO THE RULE OF LAW: ELEMENTS OF A ROADMAP
}

\author{
Geert De Baere, Anna-Luise Chané and Jan Wouters
}

\section{INTRODUCTION}

Since the beginning of the 1990s, international adjudication has undergone dramatic changes. Not only has the quantity of international judicial bodies significantly increased, today's international courts and tribunals ${ }^{1}$ also wield considerably more power than their predecessors and adjudicate an ever-growing number of cases. Over the past two decades there has been a multiplication of bodies that match the criteria of an international court or tribunal, in the sense that they are (1) permanent institutions, (2) composed of independent judges, (3) adjudicate disputes between two or more entities, at least one of which must be a State or an international organization, ${ }^{2}$ and (4) render binding decisions, (5) on the basis of predetermined procedural and substantive rules of international law. ${ }^{3}$ While up until the end of the Cold War only a handful of courts and tribunals existed, ${ }^{4}$ they have since been joined by a large number of general, specialized and regional courts and tribunals. Based on the above-mentioned criteria, more than 20 international courts currently active can be identified, ${ }^{5}$ as well as a considerable number of

\footnotetext{
${ }^{1}$ The terms 'international court' and 'international tribunal' are treated as essentially synonymous for the purposes of this paper.

${ }^{2}$ This also encompasses international criminal courts and tribunals. While states are not parties to the proceedings, an organ of the international court - the Prosecutor - brings cases against individuals.

3 Criteria used by the Project on International Courts and Tribunals (PiCT), see <http://www.pictpcti.org/matrix/matrixhome.html> accessed 15 January 2015; see similar definition applied in Cesare PR Romano, 'A Taxonomy of International Rule of Law Institutions' (2011) 2 Journal of International Dispute Settlement 241,261 et seq.

${ }^{4}$ Among them the International Court of Justice (ICJ), the European Court of Human Rights (ECtHR), the InterAmerican Court of Human Rights (IACtHR), the Court of Justice of the EU (CJEU), the Court of Justice of the Benelux Economic Union (CJBEU) and the Andean Tribunal of Justice (ATJ). See also Andreas Follesdal, 'Epilogue: reflections on international courts and tribunals' in Geert De Baere and Jan Wouters (eds), The Contribution of International and Supranational Courts to the Rule of Law (Edward Elgar, forthcoming).

${ }^{5}$ This includes the ICJ, the International Tribunal for the Law of the Sea (ITLOS) and the Appellate Body of the World Trade Organization (WTO AB), the human rights courts (ECtHR, IACtHR, African Court of Human and Peoples' Rights (ACtHPR)), the economic integration courts in Europe (CJEU, CJBEU, Economic Court of the Commonwealth of Independent States, European Free Trade Association (EFTA) Court), in Africa (Organization for the Harmonization of Corporate Law in Africa Common Court of Justice and Arbitration, East African Community Court of Justice, Economic Community of West African States (ECOWAS) Court of Justice), in the Americas (ATJ, Caribbean Court of Justice, Mercosur Dispute Settlement System, Central American Court of Justice) and in Asia (ASEAN Enhanced Dispute Settlement Mechanism) as well as the International Criminal Court (ICC), and a large number of international administrative tribunals (AT) or boards (among the international organizations which have established an AT are the African Development Bank, the Arab League, the Asian Development Bank, the Council of Europe, the EU, the European Bank for Reconstruction and Development, the European Space Agency, the European Stability Mechanism, the Inter-American Development Bank, the International Labour Organization (ILO), the International Monetary Fund (IMF), the North Atlantic Treaty Organization (NATO), the Organization for Economic Cooperation and Development (OECD), the Organization of American States (OAS), the World Bank and the UN (now UN Dispute
} 
bodies that are inactive or have a minimal case-load. ${ }^{6}$ Extending the definition to include nonpermanent adjudicative bodies, one can add a large number of ad hoc or hybrid criminal tribunals, ${ }^{7}$ arbitral tribunals ${ }^{8}$ and international claims tribunals. ${ }^{9}$

Not only the number of available tribunals has increased, but also the number of cases on their dockets and consequently their judicial output. Alter counts 3300 judicial decisions issued collectively by all international courts until 1989, and 34000 judicial decisions in the period between 1990 and $2011 .^{10}$ This increase in judicial output is certainly tied to the establishment of new adjudicative bodies, several of which have been particularly active, for example the WTO Dispute Settlement System, which generated 188 panel reports and 110 appellate reports

Tribunal and UN Appeals Tribunal). The entries listed in this and the subsequent footnotes are based on the courts identified in the following works: Karen J Alter, The New Terrain of International Law: Courts, Politics, Rights (Princeton University Press 2014) 72 et seq.; Henry G Schermers and Niels M Blokker, International Institutional Law: Unity within Diversity (5th edn, Brill 2011) 439 et seq., para 605 et seq.; Romano (n 3) 261 et seq.; Ruth Mackenzie, Cesare PR Romano, Yuval Shany and Philippe Sands, Manual on International Courts and Tribunals (OUP 2010); and William A Schabas, Solomon T Ebobrah, Carl Baudenbacher/Michael-James Clifton, David D Caron, Christoph Schreuer and Chittharanjan F Amerasinghe in the section 'Orders and Families of International Adjudicative Bodies' of The Oxford Handbook of International Adjudication edited by Cesare PR Romano, Karen Alter and Yuval Shany (OUP 2014); for more information see also the case law databases World Courts (<www.worldcourts.com/>) and WorldLII (<www.worldlii.org/int/cases/>), and the international court directory of the iCourts project (<http://jura.ku.dk/icourts/caselaw-finder/>).

${ }^{6}$ The categorization into active and inactive/less active courts varies, depending on the source. Courts that have been labelled as inactive or having a minimal caseload include e.g. the European Nuclear Energy Tribunal, the European Tribunal on State Immunity, the Judicial Tribunal of the Organization of Arab Petroleum Exporting Countries, the Court of Justice of the Economic Community of Central African States, the Judicial Organ of the Arab Maghreb Union, the Court of Justice of the African Economic Community, the Court of Justice of the West African Economic and Monetary Union, the Court of Justice of the Common Market for Eastern and Southern Africa, the Southern Africa Development Community Tribunal, the Court of Justice of the Central African Monetary Community, and the Court of Justice of the African Union; sources see above ( $n$ 5).

${ }^{7}$ These notably include the International Criminal Tribunal for the Former Yugoslavia (ICTY), International Criminal Tribunal for Rwanda (ICTR), and the UN Mechanism for International Criminal Tribunals (UNMICT), which will take over functions of the ICTY and the ICTR after the end of their mandate, the Special Court for Sierra Leone (and the Residual Special Court for Sierra Leone), the Special Tribunal for Lebanon, the Extraordinary Chambers in the Courts of Cambodia, the War Crimes Chamber of the Court of Bosnia and Herzegovina, and the most recent Extraordinary African Chambers.

${ }^{8}$ It is impossible to provide an exhaustive list of all international arbitral tribunals. Among the more permanent bodies are e.g. the Permanent Court of Arbitration, the International Joint Commission, the Bank for International Settlements Arbitral Tribunal, the International Civil Aviation Organization Council, the International Centre for the Settlement of Investment Disputes, the Gulf Cooperation Council Commission for the Settlement of Disputes, the Court of Arbitration for Sport, the North American Commission on Environmental Cooperation, the North American Free Trade Agreement (NAFTA) Dispute Settlement System, the Organization for the Harmonization of Corporate Law in Africa Common Court of Justice and Arbitration and the World Intellectual Property Organization Arbitration and Mediation Center; sources see above (n 5).

${ }^{9}$ Over the course of the nineteenth and twentieth century, almost 90 of these bodies were established (Romano ( $\mathrm{n} 3$ ) 264). Today among others the Iran-United States Claims Tribunal (IUSCT), the Marshall Islands Nuclear Claims Tribunal, and the Eritrea-Ethiopia Claims Commission remain in existence, sources see above (n 5).

${ }^{10}$ Alter only identifies two dozen international courts, see Karen Alter, 'The Multiplication of International Courts and Tribunals After the End of the Cold War', in Cesare PR Romano, Karen Alter, Yuval Shany (eds), The Oxford Handbook of International Adjudication (OUP 2014) 65, 68. 
between 1995 and 2013. ${ }^{11}$ But also pre-existing international courts have been utilized more frequently in the past decades. The International Court of Justice (ICJ), for example, has delivered 116 judgments since 1946, of which 65 alone since $1990 .^{12}$ This increased recourse to international adjudication has created a wealth of case law on many areas of international law.

In addition to this, the new generation of international courts frequently enjoys more power than their older counterparts and has taken on new roles, which indicates not only a quantitative, but also a qualitative change in the international judiciary. ${ }^{13}$ Whereas international courts were traditionally only mandated with dispute settlement between states, they today fulfil multiple functions, including the judicial review of acts and practices of domestic and international authorities, the prosecution of perpetrators of international crimes, the provision of authoritative interpretations and clarifications of the law, as well as the promotion of the development of international law. ${ }^{14}$ Whereas the international judiciary was traditionally dependent on the voluntary acceptance of its jurisdiction by the parties, several of the newer international courts have compulsory jurisdiction, and some older international courts have been granted compulsory jurisdiction through subsequent reforms. ${ }^{15}$ Finally, international adjudication is no longer a state-only affair, with more and more courts either enabling individuals to submit their claims or holding them accountable for violations of international law. ${ }^{16}$

To say that these developments have attracted a lot of scholarly attention would be an understatement. Recent years have seen numerous studies mapping the new world of international courts, ${ }^{17}$ analyzing their roles and powers, ${ }^{18}$ assessing their effectiveness, ${ }^{19}$ and

\footnotetext{
${ }^{11}$ See Peter Van den Bossche, 'The Appellate Body of the World Trade Organization' in Geert De Baere and Jan Wouters (eds), The Contribution of International and Supranational Courts to the Rule of Law (Edward Elgar, forthcoming).

12 See Philippe Couvreur, 'The International Court of Justice' in Geert De Baere and Jan Wouters (eds), The Contribution of International and Supranational Courts to the Rule of Law (Edward Elgar, forthcoming).

${ }^{13}$ Alter (n 4) 64; Jenny Martinez, 'Towards an International Judicial System' (2003) 56 Stanford Law Review 429, 438 et seq.; Christopher J Borgen, 'Transnational Tribunals and the Transmission of Norms: The Hegemony of Process' (2007) 39 George Washington International Law Review 685, 686 et seq.

${ }^{14}$ Armin von Bogdandy and Ingo Venzke, 'On the Functions of International Courts: An Appraisal in Light of Their Burgeoning Public Authority' (2012) Amsterdam Center for International Law, ACIL Research Paper No 2012/10, 2.

${ }^{15}$ See e.g. Van den Bossche (n 11). See also part XV of UNCLOS, which provides for compulsory jurisdiction but leaves the State Parties the choice of forum (ITLOS, ICJ, arbitration): see Philippe Gautier, 'The contribution of the International Tribunal for the Law of the Sea to the rule of law' in Geert De Baere and Jan Wouters (eds), The Contribution of International and Supranational Courts to the Rule of Law (Edward Elgar, forthcoming). See Protocol No 11 to the Convention for the Protection of Human Rights and Fundamental Freedoms, restructuring the control machinery established thereby, adopted 11 May 1994, entered into force 1 November 1998, ETS No 5, which established the compulsory jurisdiction of the ECtHR. However, some courts have been unaffected by this development, as exemplified by the persistently low number of states which have accepted the compulsory jurisdiction of the ICJ under art 36(2) of the Statute of the International Court of Justice (ICJ Statute) (currently 71 declarations).

${ }^{16}$ E.g. natural and legal persons may appear before the Seabed Disputes Chamber of the ITLOS (see Gautier (n 15)); individuals may bring claims before the reformed ECtHR (see Paul Lemmens, 'The contribution of the European Court of Human Rights to the rule of law' in Geert De Baere and Jan Wouters (eds), The Contribution of International and Supranational Courts to the Rule of Law (Edward Elgar, forthcoming)); the international criminal tribunals ( $n$ 5) have the competence to prosecute individuals for international crimes.

${ }^{17}$ Romano (n 3).

${ }^{18}$ See for example iCourts, the Danish National Research Foundation's Centre of Excellence for International Courts, which was created in 2012 for the study of the role and impact of international courts, <http://jura.ku.dk/icourts/>; Dinah Shelton, 'Form, Function, and the Powers of International Courts' (2009) 9 Chicago Journal of International
} 
measuring their legitimacy. ${ }^{20}$ Several scholars and practitioners have voiced concerns about the 'proliferation' of international courts, in particular referring to potentially conflicting jurisdictions and the fragmentation of international law through contradictory judgments. ${ }^{21}$ Nevertheless, the benefits of the increasing judicialization of the international order have also been highlighted, ${ }^{22}$ and the scarcity of conflicts and contradictions has been emphasized. ${ }^{23}$ Several studies suggest solutions, ranging from the avoidance of double proceedings to the establishment of a judicial dialogue among international judges. ${ }^{24}$ Nevertheless, knowledge gaps remain. In particular,

Law 537; Anna Spain, 'Examining the International Judicial Function: International Courts as Dispute Resolvers' (2011) 34 Loyola of Los Angeles International and Comparative Law Review 5; von Bogdandy and Venzke (n 14); Alter (n 5).

${ }^{19}$ Yuval Shany, Assessing the Effectiveness of International Courts (OUP 2014) and 'Assessing the Effectiveness of International Courts: A Goal-Based Approach' (2012) 106 American Journal of International Law 225, see also $226 \mathrm{fn}$ 5; Laurence R Helfer, 'The Effectiveness of International Adjudicators' in Cesare PR Romano, Karen Alter, Yuval Shany (eds) The Oxford Handbook of International Adjudication (OUP 2014) 464.

${ }^{20}$ See for example the project PluriCourts at the University of Oslo, which studies the legitimacy of international courts and tribunals from an interdisciplinary perspective, <www.jus.uio.no/pluricourts/english/>; Tullio Treves, 'Aspects of Legitimacy of Decisions of International Courts and Tribunals' with comments by Rein Müllerson, in Rüdiger Wolfrum and Volker Röben (eds), Legitimacy in International Law (Springer 2008) 169 et seq,; Yuka Fukunaga, 'Civil Society and the Legitimacy of the WTO Dispute Settlement System' (2009) 34 Brooklyn Journal of International Law 85; Nienke Grossman, 'The Normative Legitimacy of International Courts' (2013) 86 Temple Law Review 61; Koen Lenaerts, 'How the ECJ Thinks: A Study on Judicial Legitimacy' (2013) 36 Fordham International Law Journal 1302; Geir Ulfstein, 'International courts and judges: independence, interaction and legitimacy' (2014) 46 NYU Journal of International Law and Policy 849; see also the issue 'International Courts and the Quest for Legitimacy' of the Journal Theoretical Inquiries in Law, Vol. 14, Issue 2, 2013.

21 Gilbert Guillaume, 'The proliferation of international judicial bodies: The outlook for the international legal order', Speech to the Sixth Committee of the UN General Assembly, 27 October 2000 and Gilbert Guillaume, 'Advantages and Risks of Proliferation: A Blueprint for Action' (2004) 2 Journal of International Criminal Justice 300; Thomas Buergenthal, 'Proliferation of International Courts and Tribunals: Is it Good or Bad? (2001) 14 Leiden Journal of International Law, 267, 272 et seq.; JG Merrills, 'The Mosaic of International Dispute Settlement Procedures: Complementary or Contradictory?' (2007) 54 Netherlands International Law Review 361.

${ }^{22}$ See Antônio Augusto Cançado Trindade, 'Prologue: an overview of the contribution of international tribunals to the rule of law' in Geert De Baere and Jan Wouters (eds), The Contribution of International and Supranational Courts to the Rule of Law (Edward Elgar, forthcoming).

${ }^{23}$ Chester Brown, A Common Law of International Adjudication (OUP 2007); Jonathan I. Charney, 'The impact on the international legal system of the growth of international courts and tribunals' (1999) NYU Journal of International Law and Policy 697; Buergenthal (n 21) 271 et seq.; Martti Koskenniemi and Päivi Leino, 'Fragmentation of International Law? Postmodern Anxieties' (2002) 15 Leiden Journal of International Law 553; Fausto Pocar, 'The Proliferation of International Criminal Courts and Tribunals: A Necessity in the Current International Community' (2004) 2 Journal of International Criminal Justice 304; Rosalyn Higgins, 'The ICJ, the United Nations System, and the Rule of Law', Speech delivered at the London School of Economics, 13 November 2006 and Rosalyn Higgins, 'A Babel of Judicial Voices? Ruminations from the Bench' (2006) 55 International and Comparative Law Quarterly 791.

${ }^{24}$ Karin Oellers-Frahm, 'Multiplication of International Courts and Tribunals and Conflicting Jurisdiction - Problems and Possible Solutions' (2001) 5 Max Planck Yearbook of United Nations Law 67; Merrills (n 21); Nele Matz-Lück, 'Promoting the Unity of International Law: Standard-Setting by International Tribunals' in Doris König, Peter-Tobias Stoll, Volker Röben and Nele Matz-Lück (eds) International Law Today: New Challenges and the Need for Reform? (Springer 2008) 99; Nikolaos Lavranos, 'Regulating Competing Jurisdictions Among International Courts and Tribunals' (2008) 68 Zeitschrift für ausländisches öffentliches Recht und Völkerrecht 575; Suzannah Linton and Firew Kebede Tiba, 'The International Judge in an Age of Multiple International Courts and Tribunals' (2009) 9 Chicago Journal of International Law 407; Joost Pauwelyn and Luiz Eduardo Salles, 'Forum Shopping Before International Tribunals: (Real) Concerns, (Im)Possible Solutions' (2009) 42 Cornell International Law Journal 77; see also the address by Judge Schwebel to the Plenary session of the UN General Assembly on 26 October 1999, where he argued in favour of enabling international courts and tribunals to request advisory opinions from the ICJ. 
there is still a lack of understanding of the functioning of international courts and of their contribution to the rule of law at the international, regional and domestic levels.

Almost in parallel to the expansion of international adjudication, the concept of the rule of law has taken center stage. Possibly fuelled by the political changes after the end of the Cold War, the rule of law has turned into a 'panacea for the ills of countries in transition'. ${ }^{25}$ It has developed into a leitmotiv in international relations and is being referred to in countless policy documents, in various contexts. Having so far eluded a clear-cut definition, the rule of law has been employed flexibly, and is open to a variety of interpretations. ${ }^{26}$ The 2012 UN General Assembly (UNGA) Declaration of the High-level Meeting of the General Assembly on the Rule of Law at the National and International Levels ('the 2012 Declaration') ${ }^{27}$ illustrates the different facets associated with the rule of law, ranging from terrorism, to corruption, organized crime, development and conflict prevention, to name but a few. This elasticity may be expedient at the policy level, ${ }^{28}$ but its implications for the rule of law remain uncertain, particularly as regards its translation from the domestic to the international level. ${ }^{29}$

The present paper constitutes an adapted version of the introductory chapter to the book The Contribution of International and Supranational Courts to the Rule of Law ${ }^{30}$, which is forthcoming in 2015. This book aims to make a contribution to the on-going academic debate by taking a closer look at the actual functioning and work of a set of international and supranational courts and tribunals ${ }^{31}$ and by analysing their contribution to the rule of law at the international, regional and domestic levels. This paper develops an analytical framework for this purpose. After a brief historical overview of the rise of international adjudication (2), it clarifies the distinction between supranational and international bodies (3). In the light of the indeterminacy of the concept of the rule of law, we then provide an exploration of its possible conceptions (4). Subsequently, we place the international judiciary in its political context and analyse the institutional safeguards of the courts' independence and impartiality (5). Finally, we provide a preliminary comparative analysis of the many ways in which international courts may arguably strengthen the rule of law (6) and conclude by taking a closer look at the remaining challenges that the international judiciary faces today (7).

\footnotetext{
${ }^{25}$ Thomas Carothers, 'The Rule of Law Revival' (1998) 77 Foreign Affairs 95.

${ }^{26}$ See Jeremy Waldron, 'The Rule of Law and the Importance of Procedure', in: James E Fleming (ed.) Getting to the Rule of Law (NYU Press 2011) 3, 4 et seq., on the gap between formal conceptions of the term in legal philosophy, and its actual use outside the field.

${ }^{27}$ UNGA Res 67/1 (24 September 2012) UN Doc A/RES/67/1.

${ }^{28}$ Philip Alston, 'The concept of the rule of law and the way it has been dealt with at the international level', lecture held at the EIUC Venice Academy of Human Rights 2014 - 'Judicial Legitimacy and the Rule of Law', 9 July 2014.

${ }^{29}$ See below, section 4.2 .

${ }^{30}$ Geert de Baere and Jan Wouters (eds), The Contribution of International and Supranational Courts to the Rule of Law (Edward Elgar, forthcoming).

${ }^{31}$ Based on Romano's 'taxonomy' of international adjudicative bodies, a sample of courts was selected, illustrating the spectrum of international and supranational courts: a state-only court with general jurisdiction (ICJ), two state-only courts with specialized jurisdiction (International Tribunal for the Law of the Sea, Appellate Body of the World Trade Organization), a court of a regional integration organization (Court of Justice of the European Union), a human rights court (European Court of Human Rights), as well as a permanent, an ad hoc and a hybrid international criminal court (International Criminal Court, International Criminal Tribunal for the Former Yugoslavia, Special Tribunal for Lebanon respectively). In addition, the Iran-United States Claims Tribunal (IUSCT) was selected as an example of an international claims and compensations body that has made a considerable contribution to international arbitration law.
} 


\section{THE MULTIPLICATION OF INTERNATIONAL COURTS AND TRIBUNALS}

While international adjudication in the form of arbitration dates back at least to Roman times, it was only in the late nineteenth century that the idea of a permanent international court took shape. ${ }^{32}$ A standing body was considered to have several advantages, among them increased effectiveness, due to its ready availability, as well as the contribution that its case law would make to the development of international law. Proposals towards a standing international court were submitted at the First Hague Peace Conference (1899). ${ }^{33}$ Ultimately, however, the delegates could only agree on the creation of the Permanent Court of Arbitration (PCA), which famously is neither a court, nor permanent but only acts as a secretariat that facilitates arbitration between its Members. ${ }^{34}$ The Second Hague Peace Conference (1907) reached an agreement on the creation of a Permanent Prize Court, but the body never came into being. Nevertheless, the conference did sow the seeds for the later foundation of a permanent judicial body. ${ }^{35}$

It was only after the end of the First World War that a permanent international court with general jurisdiction was finally established. The Permanent Court of International Justice (PCIJ) (19221946) did not have compulsory jurisdiction over the Member States of the League of Nations, but Members could voluntarily accept the jurisdiction of the Court. Although operating in the conflict-ridden inter-war era, the PCIJ's body of case law has been widely recognized for its valuable contribution to international law, which still serves as a reference point for international courts today. ${ }^{36}$ The PClJ established the role of a permanent adjudicative body at the international level and to that extent introduced the rule of law to international relations. ${ }^{37}$

\footnotetext{
${ }^{32}$ Mary Ellen O'Connell and Lenore VanderZee, 'The History of International Adjudication' in Cesare PR Romano, Karen Alter, Yuval Shany (eds) The Oxford Handbook of International Adjudication (OUP 2014) 40.

33 ibid 47.

${ }^{34}$ Jan Wouters, 'De proliferatie van internationale rechtscolleges: goed of slecht?' in Bart Raymaekers and Gerd van
} Riel (eds) De horizonten van weten en kunnen. Lessen voor de eenentwintigste eeuw (Vol 8, Universitaire Pers Leuven 2002) 123.

${ }^{35}$ See Geert De Baere and Alex Mills, 'TMC Asser and Public and Private International Law: The Life and Legacy of "a Practical Legal Statesman"' (2011) 42 Netherlands Yearbook of International Law 28-29.

${ }^{36}$ See e.g. PCIJ, The case of the S.S. 'Lotus' (France $v$ Turkey) PCIJ Rep Series A No 10, p. 18, where the PCIJ held: 'International law governs relations between independent States. The rules of law binding upon States therefore emanate from their own free will as expressed in conventions or by usages generally accepted as expressing principles of law and established in order to regulate the relations between these co-existing independent communities or with a view to the achievement of common aims. Restrictions upon the independence of States cannot therefore be presumed'. This constitutes the so-called 'Lotus principle', according to which in international law everything that is not subject to a specific prohibition is permitted. The continued validity of the principle was challenged by the question in ICJ, Legality of the Threat or Use of Nuclear Weapons, Advisory Opinion, ICJ Reports 1996, p 226: 'Is the threat or use of nuclear weapons in any circumstance permitted under international law?' However, the ICJ held that 'the argument concerning the legal conclusions to be drawn from the use of the word "permitted", and the questions of burden of proof to which it was said to give rise, are without particular significance for the disposition of the issues before the Court' (at 239, para 22). See Martti Koskenniemi, 'Case Analysis: Faith, Identity, and the Killing of the Innocent: International Lawyers and Nuclear Weapons' (1997) 10 Leiden Journal of International Law 139-140; see also the Declaration of Judge Simma in ICJ, Accordance with International Law of the Unilateral Declaration of Independence in Respect of Kosovo, Advisory Opinion, ICJ Reports 2010, p 403, criticizing the ICJ's upholding of the Lotus principle. On the contribution of the PCIJ to international law see Ole Spiermann, International Legal Argument in the Permanent Court of International Justice (CUP 2005); and Christian Tams, Malgosia Fitzmaurice (eds) Legacies of the Permanent Court of International Justice (Brill 2013).

${ }^{37}$ Wouters (n 34) 4. 
Its reputation unscathed by the war, ${ }^{38}$ the $\mathrm{PClJ}$ was considered a success and its institutional and legal framework were therefore left largely untouched when the ICJ was created as its successor. At the same time, the International Military Tribunals of Nuremberg (1945-46) and Tokyo (1946-48) laid the groundwork for international criminal adjudication. ${ }^{39}$ But the end of the Second World War also heralded a shift of attention from the global to the regional level. On the European continent, the post-war years witnessed an increased move towards the promotion of economic integration, human rights and the rule of law. The Court of Justice of the European Coal and Steel Communities (now Court of Justice of the European Union, CJEU) ${ }^{40}$ was established in 1952, the European Court of Human Rights (ECtHR) followed in 1958. On the American continent the Inter-American Commission on Human Rights was founded in 1959, joined in 1979 by the Inter-American Court of Human Rights.

However, during the Cold War, the multiplication of international courts and tribunals slowed down. The changing political landscape after the collapse of the East-West dichotomy created the 'permissive environment' needed for the establishment of an increasing number of international courts and tribunals. ${ }^{41}$ Since the 1990s, international courts sprang up in almost all corners of the world, covering a wide range of legal areas. The majority have a jurisdiction ratione territoriae limited to a specific region. ${ }^{42}$ However, with the Appellate Body of the World Trade Organization (WTO AB, 1994), the International Tribunal for the Law of the Sea (ITLOS, 1996) and the International Criminal Court (ICC, 2002), three specialized international courts with a global reach were created. ${ }^{43}$

Nevertheless, it would be an oversimplification to regard the development of the international judiciary as a 'linear story of successes'. ${ }^{44}$ Scholarship traditionally focuses on those adjudicative bodies that have actually successfully taken up their work, thereby risking to detract from the fact that a large number of bodies exists only on paper or have fallen into a state of dormancy. Romano rightly observes that '[f]or every contemporary thriving body, there are at least twice as many that failed to set sail, or got caught in the doldrums, or even sunk after

\footnotetext{
${ }^{38}$ O'Connell and VanderZee (n 32) 56.

${ }^{39}$ See for more detail Luc Reydams and Jan Wouters, 'The Politics of Establishing International Criminal Tribunals' in Luc Reydams, Jan Wouters and Cedric Ryngaert (eds) International Prosecutors (OUP 2012) 6.

${ }^{40}$ Under the first para of art 19(1) of the Treaty on European Union (TEU) (Consolidated version of the Treaty on European Union [2012] OJ C326/13), the institution of the Court of Justice of the EU (CJEU) encompasses the Court of Justice (ECJ), the General Court (EGC) and specialized courts (at present, the EU Civil Service Tribunal).

${ }^{41}$ Alter (n 10) 75; Martinez (n 13) 437. On the impact of the end of the Cold War on the development of international law more generally, see James Crawford and Sarah Nouwen (eds), Select Proceedings of the European Society of International Law, Volume 3, 2010 (Hart 2012).

${ }^{42}$ This includes for example the ICTY and the ICTR, which were established by the UN Security Council to prosecute perpetrators of international crimes 'in the territory of the former Yugoslavia' and 'in the territory of Rwanda and [...] neighboring states' (the latter applies ratione personae only to Rwandan citizens), see Statute of the International Criminal Tribunal for the Former Yugoslavia, UNSC Res 827 (1993) UN Doc S/RES/827 (ICTY Statute) art 1, and Statute of the International Tribunal for Rwanda, UNSC Res 955 (1994) UN Doc S/Res/955 (ICTR Statute) art 1.

${ }^{43}$ There are calls for additional specialized international tribunals, for example in the areas of international human rights law, environmental law or investment law. See Julia Kozma, Manfred Nowak and Martin Scheinin, 'A World Court of Human Rights - Consolidated Draft Statute and Commentary', May 2010, $<$ www.eui.eu/Documents/DepartmentsCentres/Law/Professors/Scheinin/ConsolidatedWorldCourtStatute.pdf>; ICE Coalition - Creating the International Court for the Environment, <http://icecoalition.com>; Michael Goldhaber, 'Wanted: a world investment court' (2004) 3 Transnational Dispute Settlement.

${ }^{44}$ Cesare PR Romano, 'Trial and Error in International Judicialization' in Cesare PR Romano, Karen Alter, Yuval Shany (eds) The Oxford Handbook of International Adjudication (OUP 2014) 112.
} 
launch'. ${ }^{45}$ Examples include the European Nuclear Energy Tribunal, ${ }^{46}$ the European Tribunal on State Immunity, ${ }^{47}$ the Judicial Tribunal of the Organization of Arab Petroleum Exporting Countries (OAPEC), ${ }^{48}$ the Court of Justice of the Economic Community of Central African States (ECCAS), ${ }^{49}$ the Judicial Organ of the Arab Maghreb Union ${ }^{50}$ and the Court of Justice of the African Economic Community. ${ }^{51}$ Not much attention has been paid to these unsuccessful attempts towards international judicialization and more research is needed to analyze the underlying factors that determine the success or failure of an international court, and ultimately to create a coherent and inclusive theoretical framework.

Similarly, the conclusion that judicialization has occurred evenly would be premature, both in terms of geographic and thematic scope. ${ }^{52}$ All but five of the currently existing international courts have a jurisdiction ratione territoriae limited to a specific region and not all regions of the world are evenly judicialized. In particular, the Asian-Pacific and the Arab regions remain blank spots on the map of international adjudication. In terms of thematic coverage, judicialization has occurred mostly in the areas of human rights, international criminal law, trade, intellectual property, property and investment. ${ }^{53}$ Cases in other areas such as defence or the environment rarely reach an international tribunal and have so far not seen the creation of any specialized court. ${ }^{54}$ And even those areas that appear prima facie highly judicialized may have gaps with regard to certain issues. While for example, the competence of international human rights courts to deal with civil and political rights is widely accepted, the justiciability of economic, social and cultural rights continues to be contested. ${ }^{55}$

\footnotetext{
45 Ibid.

${ }^{46}$ The Convention on the Establishment of a Security Control in the Field of Nuclear Energy and the Protocol on the Tribunal established by the Convention were adopted in 1957 and entered into force in 1959. However, so far the court has received no cases. OECD Nuclear Energy Agency, 'European Nuclear Energy Tribunal' <https://www.oecdnea.org/law/european-nuclear-tribunal.html>.

47 The European Tribunal on State Immunity was inaugurated in 1985 but has not received a case yet. See Schermers and Blokker (n 5) 457 et seq., para 633.

${ }^{48}$ The Judicial Tribunal of the Organization of Arab Petroleum Exporting Countries (OAPEC) was established by a Protocol signed in 1978, which entered into force in 1980, see <www.oapecorg.org/Home/About-Us/OrganizationalStructure/Council-of-Ministers/Judicial-Tribunal>. At the time of writing, it had only received two cases and it is widely regarded as dormant. See Romano (n 44) 117 et seq.; Mackenzie, Romano, Shany and Sands (n 5) 250.

${ }^{49}$ The Court was created by the Treaty Establishing the Economic Community of Central African States (adopted 18 October 1983, entered into force 18 December 1984), see art 16 et seq. It is not yet operational, see <www.ceeaceccas.org/index.php/fr/a-propos-de-la-ceeac/organes-de-la-ceeac>.

50 The Judicial Organ was founded in 1989: see art 13 of the Treaty Establishing the Arab Maghreb Union (adopted 17 February 1989, entered into force 1 July 1989). It holds regular meetings but there are no public records of cases received so far, see <www.aict-ctia.org/courts_subreg/amu/amu_home.html>.

51 The Court of Justice of the African Economic Community (AEC) was established by the Treaty Establishing the African Economic Community (adopted 3 June 1991, entered into force 12 May 1994) art 18 et seq. It is considered to be dormant. See Romano ( $\mathrm{n} 44) 113$

${ }^{52}$ Ulfstein (n 20) 849.

${ }^{53}$ Cesare PR Romano, 'The Shadow Zones of International Judicialization' in Cesare PR Romano, Karen Alter, Yuval Shany (eds) The Oxford Handbook of International Adjudication (OUP 2014) 104.

54 ibid 105.

${ }^{55}$ Aoife Nolan, Bruce Porter and Malcolm Langford, 'The Justiciability of Social and Economic Rights: An Updated Appraisal' (2007) NYU Centre for Human Rights and Global Justice Working Paper Series, No 15, 1 et seq.; Michael J Dennis and David P Stewart, 'Justiciability of Economic, Social, and Cultural Rights: Should There Be an International Complaints Mechanism to Adjudicate the Rights to Food, Water, Housing, and Health?' (2004) 98 American Journal of International Law 462.
} 


\section{SUPRANATIONALISM AND INTERNATIONALISM}

The title of the volume 'The Contribution of International and Supranational Courts to the Rule of Law' suggests that a distinction can be made between international and supranational courts. But what exactly are the characteristics that set a supranational court apart from its international counterpart, and where to draw the line? The terms are often used interchangeably, which may be due to the fact that there is currently no single definition of supranationalism. Various scholars have identified different characteristics which they associate with supranational organizations. Schermers and Blokker, for example, propose the following basic indicators:

(1) The organization has the power to take decisions that are binding on the Member States.

(2) The organs taking these decisions are not entirely dependent on the cooperation of all Member States (for example composed of independent individuals, decisionmaking by majority vote).

(3) The organization has the power to adopt rules that directly bind the inhabitants of the Member States.

(4) The organization has the power to enforce its decisions, even if only through the help of an organ of the Member States.

(5) The organization enjoys some financial autonomy.

(6) No unilateral withdrawal from the organization is possible. The organization cannot be dissolved without the collaboration of it is own organs. ${ }^{56}$

While these indicators are primarily tailored to fit rulemaking organizations, they can also to a large extent be applied to judicial bodies. There is currently no organization that fulfils all of the criteria, but many match the description to various degrees. It is therefore important to consider the 'international' or 'supranational' character of a court not as an absolute value, but as a sliding scale, on which some courts are located further on the side of supranationalism, and others less so.

The different degrees of supranationalism are apparent already with regard to the first criterion. All international courts and tribunals have the power to take decisions that are binding on the Member States. For most, however, this power exists only under the condition that the respective Members have voluntarily accepted the jurisdiction of the judicial body. It might therefore be argued that judicial bodies such as the WTO AB, the ECtHR and the CJEU, which have compulsory jurisdiction over their Members, are more supranational in this respect than others such as the ICJ, for which jurisdiction is optional.

With respect to the second criterion, all selected courts and tribunals ${ }^{57}$ can issue their judgments, decisions, opinions or reports without the cooperation of their Member States. They are composed of independent judges whose freedom from external - particularly political pressures is safeguarded by various institutional means. ${ }^{58}$ With regard to the broader political

\footnotetext{
${ }^{56}$ Schermers and Blokker (n 5) 56 et seq., para 61; see also José E Alvarez, International Organizations as Lawmakers (OUP 2005) 16; Jan Klabbers, An Introduction to International Institutional Law (2nd edn, CUP 2009$) 24$ et seq.

${ }^{57}$ See supra (n 31).

${ }^{58}$ See below, section 5 .
} 
framework, however, a certain degree of political influence cannot be entirely ruled out. States retain certain means of control through their political leverage, which may be stronger or weaker, depending on the level of competition and the degree of policy diversity between the Member States. The degree of dependence may therefore impact on the internationalism or supranationalism of a court. Benvenisti and Downs, for example, consider the ICJ to be a more dependent court, due to the strong scrutiny exercised by the Permanent Members of the UN Security Council, and the ECtHR to be a more independent court, due to the high degree of competition between the Member States of the Council of Europe. ${ }^{59}$ This would support the assumption of a more pronounced supranational character of the latter, in contrast to the former.

Furthermore, supranational institutions have the power to make rules that directly bind the inhabitants of the Member States. Again, some courts fulfil this criterion to a higher degree than others. State-only courts, such as the ICJ, the WTO AB and the ITLOS, only have jurisdiction over cases between states. ${ }^{60}$ Their decisions formally only bind the parties to the dispute, although in reality they may have indirect consequences for the inhabitants of a Member State and/or the cases may largely be driven by private parties. ${ }^{61}$ Other courts appear to be more supranational in this respect. This includes in particular the international criminal courts, which decide on the international criminal responsibility of individuals. ${ }^{62}$

The last three criteria of Schermers' definition of supranationalism are less frequently matched by international courts and tribunals. In particular, in contrast to national courts, international courts are generally not backed by a reliable enforcement procedure carried out by independent authorities. Reference can be made to Article 94 of the UN Charter, an option hardly ever used, which allows the party of a judgment delivered by the ICJ to have recourse to the UN Security Council if the other party fails to meet the obligations of the judgment. ${ }^{63}$ Reference should also be made to the WTO Dispute Settlement System, which aims to ensure compliance with the outcome of cases by allowing for compensation and retaliation. Particularly the latter - selfenforcement by the Member State - is a means of exercising significant political and economic pressure on the other party, at least in cases of relative economic equality. ${ }^{64}$ Nevertheless, the enforcement mechanism for ECJ judgments is unusually strong for international law. The European Commission is responsible for ensuring that an ECJ judgment finding an infringement of EU law ${ }^{65}$ is complied with. If the Commission considers that the Member State concerned has not taken the necessary measures to comply with the judgment of the ECJ, it may bring the case before the Court. In doing so, it is to specify the amount of the lump sum or penalty payment to be paid by the Member State concerned which it considers appropriate in the circumstances. ${ }^{66}$ Furthermore, if a national court fails to comply with its obligation to follow an

\footnotetext{
59 Eyal Benvenisti and George W Downs, 'Prospects for the Increased Independence of International Tribunals' (2011) 12 German Law Journal 1057, 1060 et seq., 1073 et seq.

${ }^{60}$ Note, however, that the WTO Dispute Settlement System also has jurisdiction over the EU.

${ }^{61}$ E.g. in the framework of the WTO Dispute Settlement System, see Van den Bossche (n 11).

${ }^{62}$ Michael Zürn, 'From Interdependence to Globalization', in Walter Carlsnaes, Thomas Risse and Beth A Simmons (eds) Handbook of International Relations (Sage Publications, 2007) 247.

${ }^{63}$ See Couvreur (n 12).

${ }^{64}$ See Van den Bossche (n 11).

${ }^{65}$ See subsection 6.2 below.

${ }^{66}$ Art 260(2) TFEU. See Koen Lenaerts, Ignace Maselis and Kathleen Gutman (Janek Tomasz Nowak ed.), EU Procedural Law (OUP 2014) 208-214.
} 
ECJ judgment giving a preliminary ruling, ${ }^{67}$ infringement proceedings may be brought against that Member State. ${ }^{68}$

In addition, international courts generally do not enjoy financial autonomy - on the contrary, they are largely dependent on the financing through the Member States. ${ }^{69}$ Some courts have found themselves to be in comfortable positions, such as the ICTY and the ICTR, which are funded from the UN Peacekeeping budget and consequently enjoy comparative financial security. ${ }^{70}$ Other courts, such as the Special Tribunal for Lebanon (STL), have to rely wholly or partially on voluntary contributions. ${ }^{71}$

Finally, the Member States formally retain the power to withdraw from an international court or tribunal, to dissolve it or to change its mandate. While this may indicate that the States ultimately remain above the courts, withdrawal will mean in many cases that the State will also have to withdraw altogether from the international organization in which the court is embedded. The costs of leaving, for example, the WTO, the EU or the Council of Europe will in most cases be too high to consider withdrawal from the respective judicial bodies as a valid option. Dissolving or renegotiating necessitates political consensus on the part of all Member States, which will often be impossible to achieve. Although the Member States remain the masters of the international instrument that constituted the international court, their power may exist rather in theory than in practice - depending on the individual benefits and the political framework of the respective court.

While a clear-cut distinction between international and supranational courts is therefore impossible, they can be situated on a sliding scale from internationalism to supranationalism, based on the extent to which they match the above-mentioned criteria. Some scholars have doubted the usefulness of the concept of supranationalism; ${ }^{72}$ others have rejected it altogether. ${ }^{73}$ Nevertheless, while the concept is ill-suited to characterize an international organization in toto, it arguably has some value in highlighting particular characteristics in a certain body that indicate the extent to which it can validly be considered to be supra its Member States.

\section{THE CONCEPT OF THE RULE OF LAW}

\subsection{POINT OF DEPARTURE}

The rule of law has been variously described as an 'essentially contested concept', ${ }^{74}$ a 'bit of ruling class chatter', ${ }^{75}$ or a 'hurrah word', ${ }^{76}$ and indeed 'remains contested across both time

\footnotetext{
${ }^{67}$ Art 267 TFEU. See subsections 6.2 and 6.4 below.

${ }^{68}$ Arts 258-260 TFEU. See Lenaerts, Maselis and Gutman (n 66) 244; and see subsection 6.2 below.

${ }^{69}$ Alain Pellet, 'The Anatomy of Courts and Tribunals' (2008) 7 The Law and Practice of International Courts and Tribunals 275, 286.

${ }^{70}$ Romano (n 3) 273.

${ }^{71}$ See Agreement between the United Nations and the Lebanese Republic on the establishment of a Special Tribunal for Lebanon (adopted 22 January 2007 and 6 February 2007, entered into force 10 June 2007) (STL Agreement) art 5 , according to which $51 \%$ of the budget is to be borne by voluntary contributions of states and $49 \%$ of the budget by the Lebanese Government.

${ }^{72}$ Klabbers (n 56) 24.

${ }^{73}$ See Schermers and Blokker (n 5) 57, para 62 fn 236 for references to critical authors.

74 Jeremy Waldron, 'Is the Rule of Law an Essentially Contested Concept (In Florida)?' (2002) 21 Law and Philosophy 137-164, referring to Richard Fallon, “The Rule of Law” as a concept in Constitutional Discourse' (1997)
} 
and geography'. ${ }^{77}$ This paper acknowledges those contestations and contradictions, but nevertheless takes as a point of departure for its enquiry the link between the national and international judiciary and the rule of law as highlighted in the 2012 Declaration. ${ }^{78}$ There, the UNGA recognized that the rule of law applies to all States equally, and to international organizations, including the United Nations and its principal organs, and that respect for and promotion of the rule of law and justice should guide all of their activities and accord predictability and legitimacy to their actions. ${ }^{79}$ The 2012 Declaration affirms that the independence of the judicial system, together with its impartiality and integrity, is an essential prerequisite for upholding the rule of law and ensuring that there is no discrimination in the administration of justice, and emphasizes the right of equal access to justice for all, including members of vulnerable groups. ${ }^{80}$ The 2012 Declaration also commits to ensuring that impunity is not tolerated for genocide, war crimes and crimes against humanity or for violations of international humanitarian law and gross violations of human rights law, and that such violations are properly investigated and appropriately sanctioned, including by bringing the perpetrators of any crimes to justice, through national mechanisms or, where appropriate, regional or international mechanisms, and explicitly recognizes the role of the ICC in a multilateral system that aims to end impunity and establish the rule of law. ${ }^{81}$ Finally, the 2012 Declaration also recognizes the positive contribution of the ICJ, the principal judicial organ of the United Nations, including in adjudicating disputes among States, and the value of its work for the promotion of the rule of law, and indeed the contributions of the ITLOS, as well as other international courts and tribunals, in advancing the rule of law at the international and national levels. ${ }^{82}$

This paper proceeds on the working assumption that, at its most basic, the rule of law can arguably be described as a principle that all individuals and entities, including states and international organizations, are to be subject to and accountable to the law. ${ }^{83}$ That implies the subjection of individuals and all levels of public power in the national and international realm to legal constraints with a view to guaranteeing the equal protection of all individuals against

97 Columbia L Rev 6, citing Walter Bryce Gallie, 'Essentially Contested Concepts' (1955-1956) 56 Proceedings of the Aristotelian Society 167.

${ }^{75}$ Judith Shklar, 'Political Theory and the Rule of Law' in Alan Hutchinson and Patrick Monahan (eds) The Rule of Law: Ideal or Ideology (Carswell 1987) 1: "It would not be very difficult to show that the phrase "the Rule of Law" has become meaningless thanks to ideological abuse and general over-use . . . No intellectual effort need therefore be wasted on this bit of ruling-class chatter'.

${ }^{76}$ Stéphane Beaulac, 'The Rule of Law in International Law Today' in Gianluigi Palombella and Neil Walker (eds) Relocating the Rule of Law (Hart Publishing 2009) 222-223, who argues that 'the rule of law' is a formulation of 'Hurrah!' words, i.e. words that provoke a positive emotion as used by Charles Kay Ogden and Ivor Armstrong Richards, The Meaning of Meaning: A Study of the Influence of Language upon Thought and of the Science of Symbolism (Harcourt Brace Jovanovich 1923).

${ }^{77}$ Simon Chesterman, 'An International Rule of Law?' (2008) 56 AJCL 340.

${ }^{78}$ UN Doc A/RES/67/1.

${ }^{79}$ ibid, para 2.

${ }^{80}$ ibid, paras 13-14.

81 ibid, paras 22-23.

82 ibid, paras 31-32.

${ }^{83}$ That core aspect is expressed cogently and concisely in Thomas Fuller's phrase 'Be you never so high, the Law is above you': Thomas Fuller, Gnomologia: Adagies and Proverbs; Wise Sentences and Witty Sayings, Ancient and Modern, Foreign and British (Barker and Bettesworth and Hitch 1732) sentence no 943, quoted by Lord Denning MR in Gouriet v Union of Post Office Workers [1977] QB 729, 762, and by Tom Bingham, The Rule of Law (Allen Lane 2010) 4. See further Geert De Baere, 'European Integration and the Rule of Law in Foreign Policy' in Julie Dickson and Pavlos Eleftheriadis (eds), Philosophical Foundations of European Union Law (OUP 2012) 354-383, arguing that that principle as applied to public authorities, particularly those involved in foreign policy, is the cornerstone of European integration. 
arbitrary or unlawful use of power. ${ }^{84}$ That also entails a number of minimal characteristics, such as that law must be prospective, public, general, clear, stable, certain and applied to everyone equally according to its terms ${ }^{85}$ As Follesdal notes ${ }^{86}$ at least part of the justification of those characteristics can be based on two interests of individuals: our interest in non-domination, that is the 'protection from the arbitrary use of political authority and coercive power', ${ }^{87}$ and in predictability, that is 'our ability to make longer term plans in pursuit of our various interests with some expectation of success - in particular, to be able to rely on general compliance with legal rules' ${ }^{88}$ That leaves room for various more or less formal or substantive conceptions of the rule of law that are more or less expansive in what they encompass.

A notable maximalist or substantive conception of the rule of law was put forward by UN Secretary-General Kofi Annan in his 2004 report The rule of law and transitional justice in conflict and post-conflict societies: ${ }^{89}$

\begin{abstract}
The "rule of law" is a concept at the very heart of the Organization's mission. It refers to a principle of governance in which all persons, institutions and entities, public and private, including the State itself, are accountable to laws that are publicly promulgated, equally enforced and independently adjudicated, and which are consistent with international human rights norms and standards. It requires, as well, measures to ensure adherence to the principles of supremacy of law, equality before the law, accountability to the law, fairness in the application of the law, separation of powers, participation in decision-making, legal certainty, avoidance of arbitrariness and procedural and legal transparency.
\end{abstract}

As Crawford notes, these precepts were articulated in the context of an international organization with international legal personality and a mandate to support domestic transitional justice. They arguably require adaptation before they can be applied to the system of international law as a whole. ${ }^{90}$ Moreover, even at the UN level, contrasting conceptions of the rule of law exist, notably on whether human rights are included in the rule of law, or alternatively, whether they are a necessary complement of the rule of law, but not included in it. As pointed out by Follesdal, ${ }^{91}$ the latter is what the 2012 Declaration appears to suggest. There, the Heads of State and Government, and heads of delegation reaffirm ...that human rights, the rule of law and democracy are interlinked and mutually reinforcing and that they
belong to the universal and indivisible core values and principles of the United Nations. ${ }^{92}$

They also express their conviction

\footnotetext{
${ }^{84}$ Compare the similar conception in Chesterman (n 77) 342; and James Crawford, 'Chance, Order, Change: The Course of International Law. General Course on Public International Law' (2013) 265 Collected Courses of The Hague Academy of International Law 271.

${ }^{85}$ Brian Tamanaha, 'A Concise Guide to the Rule of Law' in Gianluigi Palombella and Neil Walker (eds) Relocating the Rule of Law (Hart Publishing 2009) 3. See also the eight desiderata in Lon Fuller, The Morality of Law (Revised edn, Yale UP 1969) 38-39; the eight desiderata in John Finnis, Natural Law and Natural Rights (2nd edn, OUP 2011) 270-271; and the eight principles in Joseph Raz, The Authority of Law (2nd edn, OUP 2009) 214-219; and compare the definition of the rule of law in Friedrich Von Hayek, The Road to Serfdom (Routledge 1944) 54. See also the somewhat different list of features 'arguably necessary if the international legal system can be said to be governed by the rule of law' in Crawford ( $\mathrm{n}$ 84) 253.

${ }^{86}$ See Follesdal (n 4).

${ }^{87}$ P Pettit, Republicanism: A Theory of Freedom and Government (Clarendon Press 1997).

${ }^{88}$ See Raz (n 85).

${ }^{89}$ UN Security Council, The rule of law and transitional justice in conflict and post-conflict societies. Report of the Secretary-General (UN Doc S/2004/616) para 6.

${ }^{90}$ Crawford (n 84) 262

${ }^{91}$ Follesdal (n 4).

92 UN Doc A/RES/67/1, para 5.
} 
...that the advancement of the rule of law at the national and international levels is essential for sustained and inclusive economic growth, sustainable development, the eradication of poverty and hunger and the full realization of all human rights and fundamental freedoms, including the right to development, all of which in turn reinforce the rule of law... ${ }^{93}$

Finally, the Heads of State and Government, and heads of delegation emphasize

the importance of continuing our consideration and promotion of the rule of law in all its aspects, and to that end we decide to pursue our work in the General Assembly to develop further the linkages between the rule of law and the three main pillars of the United Nations: peace and security, human rights and development... 94

This paper is not intended as a further examination of the merits or demerits of formal or substantive rule of law conceptions ${ }^{95}$ or of more or less comprehensive conceptions including or not the respect for human rights. It aims to do no more than set out an analytical framework to assess the contribution of international and supranational courts to the rule of law at international, regional, and domestic levels, while leaving room for various institutional and individual conceptions in that regard.

\subsection{THE RULE OF LAW IN THE INTERNATIONAL LEGAL ORDER}

The rule of law (or its equivalents in other languages) was originally developed to be applied to and within states, ${ }^{96}$ as a glance at the names of the equivalent (though not entirely identical) concepts in a number of other languages makes clear. ${ }^{97}$ Does the origin of the rule of law in a national context imply that it is, as Crawford asks, 'still extraneous to the real hard business of international law, like an accidental tourist at a diplomatic conference? ${ }^{\prime 98}$ That is clearly not a forgone conclusion. In fact, the 'domestic' origin does not seem to stand in the way of the application of the rule of law, in its core meaning, to other entities, both at national and international levels. ${ }^{99}$ Arguably, there can be no clear-cut distinction between the state and other public or quasi-public bodies from the perspective of the elimination of arbitrary power. ${ }^{100}$ As the ICJ put it in ELSI: 'Arbitrariness is not so much something opposed to a rule of law, as something opposed to the rule of law'. ${ }^{101}$

\footnotetext{
${ }^{93}$ Ibid, para 7.

94 Ibid, para 41.

${ }^{95}$ See further Paul Craig, 'Formal and Substantive Conceptions of the Rule of Law: An Analytical Framework' [1997] PL 467-487; an eminent example of the former is Raz (n 85), and of the latter Ronald Dworkin, A Matter of Principle (Harvard UP 1985) 11-12. See specifically with respect to the international level: Hans Corell, 'A Challenge to the United Nations and the World: Developing the Rule of law' (2004) 18 Temple International and Comparative Law Journal 391, 393.

${ }^{96}$ The phrase 'rule of law' itself originates from Albert Venn Dicey, Introduction to the Study of the Law of the Constitution (6th edn, Macmillan 1902).

${ }^{97}$ Eg Rechtsstaat, Etat de droit, Stato di diritto, Estado de derecho.

${ }^{98}$ Crawford (n 84) 257.

${ }^{99}$ See in that sense UN General Assembly and Security Council, Uniting our strengths: Enhancing United Nations support for the rule of law. Report of the Secretary-General (UN Doc A/61/636-S/2006/980).

100 See Trevor Allan, Constitutional Justice: a Liberal Theory of the Rule of Law (OUP 2001) 11.

101 ICJ, Elettronica Sicula SpA (Elsi), Judgment, ICJ Reports 1989, 76, para 128, referring to what it had held in the Asylum case, when it spoke of 'arbitrary action' being 'substituted for the rule of law' (ICJ, Asylum, Judgment, ICJ Reports 1950, p 284).
} 
That said, the manner in which the rule of law is applied to international institutions and the international legal order in general needs to take into account the fact that, compared to most states, the international legal order has a varying but generally weaker degree of institutionalisation, lacks a centralised and hierarchical structure, and is hence organized along horizontal rather than vertical lines. ${ }^{102}$ That also implies the correlative need for many decisions to be taken by consensus, if at all. ${ }^{103}$ As will be seen, the absence of a central legislature in the international legal order also impacts on the role and the operation of international and supranational courts. ${ }^{104}$

Furthermore, account must be taken of the divergent meanings given to the equivalent concepts in various systems, especially as failing to take account of local traditions may be a major stumbling block in promoting the rule of law. ${ }^{105}$ Much like with respect to human rights, a consensus on the rule of law cannot be achieved by ignoring pre-existing traditions, but by different groups, within their own heritage, 'travelling different routes to the same goal. ${ }^{106}$ The importance of that diversity is also acknowledged by the United Nations, notably in the 2008 Report of the Secretary General and in the 2012 Declaration. In his 2008 Report, the SecretaryGeneral argued that in fulfilling its responsibilities, the UN must work towards achieving appropriate application at the international level of the Organization's understanding of the principle of the rule of law. However, efforts to do so 'must be based on commonly agreed values', which are to be drawn from existing commitments in the UN, the Declaration on Principles of International Law concerning Friendly Relations and Cooperation among States, ${ }^{107}$ the 2005 World Summit Outcome Document ${ }^{108}$ and multilateral treaties. ${ }^{109}$ In the 2012 Declaration, the Heads of State and Government, and heads of delegation recognized 'the progress made by countries in advancing the rule of law as an integral part of their national strategies', and 'that there are common features founded on international norms and standards which are reflected in a broad diversity of national experiences in the area of the rule of law', stressing 'the importance of promoting the sharing of national practices and of inclusive dialogue'. ${ }^{110}$ International law does not exist to exhort or enforce a homogenous set of values at all costs, but in large areas allows states to be different. As Vaughan Lowe put it: 'International law deals in polyphony, not in plainsong.'.11

International law constrains the unlimited exercise of power by states through subjecting their behaviour to a set of rules. That not only makes their behaviour compatible with similar behaviour of other states and actors in international law, but also makes it more predictable and

\footnotetext{
102 Jan Wouters and Matthieu Burnay, 'The International Rule of Law: European and Asian Perspectives' (2013) Revue belge de droit international 299, 300.

${ }^{103}$ Crawford (n 84) 261.

${ }^{104}$ See subsection 4.3 and section 7 below.

${ }^{105}$ Rosa Ehrenreich Brooks, 'The New Imperialism: Violence, Norms and the "Rule of Law"' (2003) 101 Michigan Law Review 2275, 2322.

${ }^{106}$ Charles Taylor, 'Conditions for an Unforced Consensus on Human Rights' in Joanne Bauer and Daniel Bell (eds) The East Asian Challenge for Human Rights (CUP 1999) 144.

107 UN General Assembly, Declaration on Principles of International Law Concerning Friendly Relations and Cooperation among States in Accordance with the Charter of the United Nations (UN Doc A/RES/25/2625).

${ }^{108}$ UN General Assembly, 2005 World Summit Outcome (UN Doc A/RES/60/1).

109 UN General Assembly, Strengthening and coordinating United Nations rule of law activities. Report of the Secretary-General (UN Doc A/63/226) paras 24-25.

${ }^{110}$ ibid, para 10.

${ }^{111}$ Vaughan Lowe, 'The Function of Litigation in International Society' (2012) 61 International and Comparative Law Quarterly 221.
} 
hence creates opportunities for individuals to act freely and autonomously. ${ }^{112}$ Rules establish expectations for individuals. If the bases of these rules and claims are unsure, 'so are the boundaries of men's liberties'. ${ }^{113}$ In that sense, too extensive a conferral of discretion upon public authorities may invite the judgement that the regime in question is a marginal instance of a legal ordering. If discretion is too broadly conferred, individuals will have to guide their conduct by prediction of official behaviour, rather than by legal rules. This also means that the rule of law implies independence of the power of others, and is not content with mere predictability in action by public authorities: 'even when we are fully under the power of the unconstrained will of our governors, the exercise of that power may be highly predictable'. ${ }^{114}$ That is true of all public authorities, from the local to the international level, even if international organizations do not as a rule aim at the monopoly of the use of force in a specific territorial circumscription. ${ }^{115}$ Nevertheless, the risk of discretionary competences that are too broad in scope is often higher in the international action of states, which is traditionally the domain of the executive, with often little involvement of the legislature or the judiciary. For example, an international rule of precedence such as Article 103 of the UN Charter, which provides that in case of conflict, obligations under the Charter prevail over obligations under any other international agreement, can have the effect not of limiting the discretionary power of an essentially executive organ such as the Security Council, but of expanding it at the expense of rule of law constraints, democratic accountability, and the rights of individuals. ${ }^{116}$ The peace and security powers given to or asserted by the UN Security Council and the unusual relationship to other legal regimes due to Article 103 of the UN Charter may lead to questioning whether the UN may properly be said to embody the rule of law in a meaningful way. ${ }^{117}$ In short, there exists an inherent contradiction between the rule of law and the notion of a purely administrative or discretionary act that determines a citizen's fate without recourse to legal safeguards, ${ }^{118}$ and such acts are arguably more common in international action than in internal action.

Clearly therefore, an individual's liberties are as much at stake when the state acts externally as when it acts internally. Indeed, many more individuals may be affected by the state's external action than by its internal action. Moreover, lawless state action in the international realm may entail lawless state action at home, as abuses in the government's treatment of others abroad can creep back in and insinuate themselves into domestic state practice, infecting and

\footnotetext{
112 This is arguably the 'raison d'être of the rule of law': Jeremy Waldron, 'The Rule of International Law' (2008) 30 Harvard J of L \& Public Policy 17. See also Amanda Perreau-Saussine, 'Immanual Kant on International Law' in S Besson and J Tasioulas (eds) The Philosophy of International Law (OUP 2010) 55, noting that for Kant, 'the closer a state approaches perpetual peace with its potential enemies, the more secure citizens' juridical freedom will be'. See also De Baere (n 83) 358.

113 John Rawls, A Theory of Justice (Revised edn, Belknap 1999) 207.

${ }^{114}$ Nigel Simmonds, Law as a Moral Idea (OUP 2007) 90, but also 46 and 98.

115 Alan Buchanan, and Robert Keohane, 'The Legitimacy of Global Governance Institutions' (2006) Ethics and International Affairs 406.

116 Jean Cohen, Globalization and Sovereignty. Rethinking Legality, Legitimacy, and Constitutionalism (CUP 2012) 291. The tension between the obligations under art 103 UN Charter and the rule of law at the level of the EU was famously the subject of the Kadi litigation before the EU courts: see the EGC judgments in Kadi $v$ Council and Commission, T-315/01, EU:T:2005:332 and Kadi v Commission, T-85/09, EU:T:2010:418; and the ECJ judgments in Kadi and Al Barakaat International Foundation $v$ Council and Commission, C-402/05 P and C-415/05 P, EU:C:2008:461 and Commission, Council and UK v Kadi, C-584/10 P, C-593/10 P and C-595/10 P, EU:C:2013:518. See Koen Lenaerts, 'The Court of Justice as the guarantor of the rule of law within the European Union' in Geert De Baere and Jan Wouters (eds), The Contribution of International and Supranational Courts to the Rule of Law (Edward Elgar, forthcoming); and further De Baere (n 83) 374-383.

${ }^{117}$ Chesterman (n 77) 354.

${ }^{118}$ Allan (n 100) 174
} 
contaminating the culture of legality at home. As Waldron put it: the 'governmental character of the nation-state does not evaporate when we move up a level to the international realm'. ${ }^{119}$ Furthermore, the strong global interdependence causes individuals and groups often to be affected more readily by the actions of other states than by those of the state in which they live or of which they are nationals. However, the existing international legal order, subdivided as it is in sovereign and equal states, does not allow individuals to be included in decision-making processes that cover competences of other states or political communities, but the outcome of which will nevertheless affect their life and wellbeing. ${ }^{120}$

Governments should therefore proceed on the basis that they are to act both internally and externally in accordance with law in all of their operations, and thus subject themselves to constraint by law so that citizens can enjoy freedom under law. ${ }^{121}$ That idea is reflected in Article 14 of the Draft Declaration on Rights and Duties of States: ${ }^{122}$

Every State has the duty to conduct its relations with other States in accordance with international law and with the principle that the sovereignty of each State is subject to the supremacy of international law.

Depending on the sources of rule of law constraints and the public authorities to which they apply, a distinction could in that regard be drawn between an external and an internal aspect of the rule of law. ${ }^{123}$ The sources of external rule of law constraints are legal orders that include but are broader in scope than the legal order whose public authorities they are meant to constrain; for example, constraints on states imposed by an international organization of which they are a member, but equally constraints on international organizations imposed by general international law. The sources of internal rule of law constraints are the legal orders themselves whose public authorities are to be constrained; for example, constraints imposed by the internal law of those states or international organizations. In both cases, those constraints can pertain to public authority action within the legal order; that is, internal or (for states) domestic policy, and public authority action outside the legal order; that is, external or (for states) foreign policy. An example of an external rule of law constraint on foreign policy is the prohibition on the threat or use of force in international relations contained in Article 2(4) of the UN Charter. An example of an external rule of law constraint on internal or domestic policy is the right not to be subjected to torture as guaranteed by Article 3 of the European Convention on Human Rights (ECHR). An example of an internal rule of law constraint to external or foreign policy would be the possibility

\footnotetext{
119 Jeremy Waldron, 'Are Sovereigns Entitled to the Benefit of the International Rule of Law?' (2011) 22 Eur J Intl L 341-342. See Mark Reiff, 'The Attack on Liberalism' in Michael Freeman and Ross Harrison (eds) Law and Philosophy (OUP 2007) 181-3. See also De Baere (n 83) 358-359.

120 Ronald Dworkin, 'A New Philosophy for International Law' (2013) Philosophy and Public Affairs 18 and 28-29. Nevertheless, a distribution of decision-making authority based purely on who is affected by a specific decision would lead to complex procedural difficulties and problems of interaction and overlap: see e.g. Andreas Follesdal, 'Subsidiarity and the Global Order' in Michelle Evans and Augusto Zimmermann (eds), Global Perspectives on Subsidiarity (Springer 2014) 214-215; and see with respect to the EU Nick Barber, 'The Limited Modesty of Subsidiarity' (2005) ELJ 317; Alexia Herwig, 'Federalism, the EU and International Law: On the Possible (and Necessary) Role of Subsidiarity in Legitimate Multilevel Trade Governance' in Elke Cloots, Geert De Baere and Stefan Sottiaux (eds), Federalism in the European Union (Hart Publishing 2012) 68.

${ }^{121}$ Waldron (n 119) 340, arguing also that the government's own freedom of action is not an intrinsic value as it is for individual citizens.

${ }_{122}$ Draft Declaration on Rights and Duties of States, 1949 YB Int'I L Comm'n 178. On the relationship between sovereignty and the rule of law, see eg John Rawls, Lectures in the History of Political Philosophy (Belknap Press 2007) 86; and Pavlos Eleftheriadis, 'Law and Sovereignty' (2010) 29 Law and Philosophy 535-569. Further: Sir Neil MacCormick, Questioning Sovereignty: Law, State, and Practical Reason (OUP 1999); Katrin Flikschuh, 'Kant's Sovereignty Dilemma: A Contemporary Analysis' (2010) 18 The Journal of Political Philosophy 469-493.

${ }^{123}$ De Baere (n 83) 355.
} 
for courts to review the compliance of an international agreement with internal constitutional principles. An example of an internal rule of law constraint to internal or domestic policy would be the possibility for courts to review the legality of police action by a state on its own territory. As will be explored further below, ${ }^{124}$ by assessing the compliance by public authorities with international law constraints, international and supranational courts can contribute to internal rule of law constraints within the organizations of which they are an organ (internal compliance assessment), as well as to the external rule of law constraints on states subject to their jurisdiction (external compliance assessment). In turn, those external rule of law constraints imposed by international and supranational courts may contribute to the internal rule of law constraints on states imposed by their own courts or administrations.

For states, rule of law constraints may be regarded as limiting their freedom of action. ${ }^{125}$ It has been often argued that in an unpredictable world states must not be constrained by rules that prevent them from acting quickly and decisively. ${ }^{126}$ States may well take the view that they can only allow themselves to be so constrained if the behaviour of other international actors can be predicted because it is governed by rules. That is arguably why foreign policy has frequently been claimed to escape any grasp of law. ${ }^{127}$ On the internal level, it is often held that the penetration of law into foreign policy should be kept to a minimum: the executive must have its hands free to react to international developments quickly and effectively, without interference from the legislature or the judiciary. ${ }^{128}$ On the international level, a similar attitude has sometimes led to the rejection of the legal character of international law, ${ }^{129}$ or the downplaying of its significance. ${ }^{130}$

Conversely, international law can nevertheless often also be actively used by states to achieve particular objectives that they find difficult to achieve using purely internal means. ${ }^{131}$ It can, for example be used to entrench rules that are not easily subject to entrenchment by ordinary statute. ${ }^{132}$ Indeed, politicians may even use international courts or other independent dispute settlement organs instead of bilateral negotiations so as to avoid the political costs of

\footnotetext{
${ }^{124}$ See section 6.2 below.

${ }^{125}$ De Baere (n 83) 359-360.

${ }^{126}$ See e.g. notably James Madison, Alexander Hamilton, John Jay, The Federalist Papers (J \& A McLean 1788) XXIII and XLI.

127 See Thomas Franck, Political Questions/Judicial Answers: Does the Rule of Law Apply to Foreign Affairs? (Princeton UP 1992) 49, reviewed in Anne-Marie Slaughter, 'Are Foreign Affairs Different?' (1993) Harvard L Rev 1980-2008; and see Alter (n 5) 3.

${ }^{128}$ See Franck (n 127) 3-4, who refers to 'a constitutional theory, still asserted by many lawyers and judges, that foreign affairs are different from all other matters of state in some crucial fashion . . Carried to its logical extreme, this doctrine holds that the political authorities are suit-proof as long as they purport to act in pursuance of their "foreign-affairs" power'.

${ }^{129}$ Famously John Austin, The Province of Jurisprudence Determined (Wilfrid Rumble (ed) CUP 1832/1995) 20 et passim, also classifying constitutional law as 'positive morality merely': at 216 et passim. But see Thomas Franck, Fairness in International Law and Institutions (Clarendon Press 1995) 6, arguing that international law has entered a 'post-ontological era', enabling international lawyers to 'undertake critical assessment' of their subject, instead of continuously having to defend its existence. See James Brierly, The Law of Nations: An Introduction to the International Law of Peace (4th edn, Clarendon Press 1949) 73.

${ }^{130}$ Eg Herbert Hart, The Concept of Law (2nd edn, OUP 1994) 198, remarking that law in the international system has been confined to matters that do not 'affect "vital" issues'.

${ }^{131}$ De Baere (n 83) 360.

${ }^{132}$ For example, bilateral investment treaties (BITs) can resolve the problem that a state cannot make a commitment to an investor under national law, because it may be unable securely to bind itself domestically: Alex Mills, 'The Public-Private Dualities of International Investment Law and Arbitration' in Chester Brown and Kate Miles (eds) Evolution in Investment Treaty Law and Arbitration (CUP 2011) 97.
} 
negotiating a deal that may be not as attractive to their constituents as other options. ${ }^{133}$ Moreover, states often do regard themselves bound by certain constraints regardless of whether other international actors are so constrained. For example, many states would hold themselves bound by an obligation not to torture prisoners, regardless of whether other states or international actors are under the same obligation. ${ }^{134}$

Crucially, international courts provide an important method for states to bind themselves without the danger of facing an 'unbound' opponent. Conferring jurisdiction, especially compulsory jurisdiction, to an international court is a tool for states to bind other states and to create the background conditions for the law to be implemented and respected by all parties. ${ }^{135} \mathrm{In}$ other words, accepting the jurisdiction of international courts makes the mutual commitments between states credible, which may provide an incentive for their creation. ${ }^{136}$ In addition, while under a contract-based conception of international obligations, the breach by one party of its obligations releases or modifies the obligations of the other party, international law has arguably seen a shift toward expectations of compliance grounded in the rule of law, regardless of what other parties may be doing. That shift is most visible in the operation of international courts. ${ }^{137}$

\subsection{THE RULE OF LAW AND INTERNATIONAL COURTS}

As noted by Waldron, principles (such as the rule of law) 'cannot conduct distributions by themselves: they must be administered by working institutions', and 'to the extent that the avoidance of injustice is a moral imperative, the establishment of coordinating institutions is a moral imperative'. ${ }^{138}$ The establishment of international and supranational courts is to be understood against that background. ${ }^{139}$

The possibility of access to an independent judiciary and of judicial review is an essential aspect in many understandings of the rule of law. ${ }^{140}$ The judiciary's crucial role of preventing discrepancy between the law as declared and as administered, ${ }^{141}$ ensuring that legal rules prevail over power in the settlement of disputes, ${ }^{142}$ and rendering the law clearer, more

\footnotetext{
${ }^{133}$ Benedict Kingsbury, 'International courts: uneven judicialisation in global order' in James Crawford and Martti Koskenniemi (eds) The Cambridge Companion to International Law (CUP 2012) 216.

${ }^{134}$ A liberal state may, for example, take the view that resorting to torture would undermine the basis of the proper constitutional relationship between state and citizen: see Allan (n 100) 83-84. Further: Jeremy Waldron, Torture, Terror, and Trade-Offs: Philosophy for the White House (OUP 2010).

${ }^{135}$ Alter (n 5) 10-11

${ }^{136}$ Kingsbury (n 133) 217.

${ }^{137}$ Alter (n 5) 18-19.

138 Jeremy Waldron, 'Special Ties and Natural Duties' (1993) 22 Philosophy \& Public Affairs 15 and 28. See Pavlos Eleftheriadis, Legal Rights (OUP 2008) 56, arguing that the creation of legal institutions is a matter of a special moral duty and that the successful function of law is therefore a distinct moral requirement.

139 See De Baere (n 83) 362, arguing that the establishment of the EU and its institutions and the rule of law as the cornerstone of that project of European integration are to be understood against that same background.

${ }^{140}$ On the merits and demerits of judicial review in constitutional systems, see e.g. Jeremy Waldron, 'The Core of the Case against Judicial Review' (2006) Yale LJ 1346-406; Richard Fallon, 'The Core of an Uneasy Case For Judicial Review' (2008) Harvard L Rev 1693-763; Mark Tushnet, 'How Different are Waldron's and Fallon's Core Cases For and Against Judicial Review?' (2010) 30 OJLS 49-70. See also John Rawls, Political Liberalism (Expanded edn, Columbia UP 2005) 339.

${ }^{141}$ Fuller (n 85) 81; see Jeremy Waldron, 'The Concept and the Rule of Law' (2008) 43 Georgia L Rev 1, 20, arguing that absent the existence and operation of the sort of institutions we call courts, something should not be regarded as a legal system. See also Allan (n 100) 43.

${ }^{142}$ Nicolas Hachez, 'What elements of the rule of law can be put to use at international level?' (2013) Revue belge de droit international 307, 311.
} 
predictable, and more coherent, makes international and supranational courts a logical focal point for a discussion of the rule of law at the international, regional and national levels. ${ }^{143}$

For Hans Kelsen, the judicial process is the foundation of each legal organisation and every community of law, and the introduction of a judicial organ with compulsory jurisdiction is the turning point in the transition from a decentralized legal order to a more centralized and more effective legal order. ${ }^{144}$ In the international legal order, that process is still in its infancy, as judicial dispute settlement remains an exception to the rule of autonomous interpretation by states of their international obligations and free choice of means of peaceful dispute settlement. ${ }^{145}$ Indeed, Grotius felt perfectly comfortable putting forward the idea of an international legal order based on rights, duties, and rules of conduct, but without courts. ${ }^{146}$ Nevertheless, as Alter has powerfully demonstrated, international courts play an ever-increasing central role in the debate about the meaning of international law and about what respect for the rule of law by governments entails. Their contribution rests in their independent ability to state what the law is, point out violations, indicate remedies, and increase the credibility of the consequences of non-compliance with international rules. They further effectuate change by working with actors in various guises and combinations that for various reasons want to see international law respected. ${ }^{147}$

International courts and tribunals adjudicate disputes not on the basis of political discretion, but on the basis of previously established rules. ${ }^{148}$ They thus contribute to a situation in which not physical force and the arbitrariness and oppressiveness of power contests but a system of rules is the manner in which disputes are to be settled, thereby representing the normative ideal of the rule of law. ${ }^{149}$ Nevertheless, international courts not only settle disputes, but especially in the absence of an international legislature, also contribute to the development of the law. ${ }^{150}$ Indeed, dispute settlement may currently no longer be the task most often given to an international court, nor its most often performed function. ${ }^{151}$

The diversity of the contexts in which the rule of law at international level operates mentioned above also has clear consequences for the operation of courts. While domestic courts work against the background of a shared minimum set of common values, such commonality is often very thin in the international legal order. International courts and tribunals are therefore faced with a fraught balancing act between different legal and moral systems. ${ }^{152}$ Indeed, the key difference between national and international law in that regard may be that the latter must compete with domestic rule of law conceptions. Governments may therefore try to justify their disregard for decisions of international courts and tribunals by arguing that they are inconsistent with the domestic conception of the rule of law. ${ }^{153}$ Moreover, and partly as a consequence, the

\footnotetext{
143 See De Baere (n 83) 367-368.

${ }^{144}$ Hans Kelsen, Peace Through Law (The University of North Carolina Press 1944) 73. See Charles Leben, 'Hans Kelsen and the Advancement of International Law' (1998) 9 EJIL 287, 291-292. Further: Jochen von Bernstorff, The Public International Law Theory of Hans Kelsen: Believing in Universal Law (CUP 2010) 191-224.

${ }^{145}$ See art 33 UN Charter. Further Andreas Paulus, 'International Adjudication' in Samantha Besson and John Tasioulas (eds) The Philosophy of International Law (OUP 2010) 207.

${ }^{146}$ As pointed out by Kingsbury (n 133) 203, referring to Hugo Grotius, De jure belli ac pacis (1625).

${ }^{147}$ Alter (n 5) 4-5 and 28.

${ }^{148}$ Paulus (n 145) 217-219.

${ }^{149}$ Hachez (n 142) 308.

${ }^{150}$ Lowe (n 111) 212-214.

${ }^{151}$ Alter (n 5) 12-13. See section 6 below.

${ }^{152}$ Paulus (n 145) 213.

${ }^{153}$ Alter (n 5) 8 and 20.
} 
difficulties for international courts and tribunals start at the level of sources, which are notoriously more difficult to identify than in domestic legal systems. In the absence of an international legislator, a consequence of what Dworkin described as the unmitigated Westphalian system', ${ }^{154}$ international judges must find the law before being able to apply it. ${ }^{155}$ The political context within which international courts and tribunals operate is therefore of crucial importance in order to understand their functioning.

\section{INDEPENDENCE AND IMPARTIALITY}

International courts and tribunals do not exist in a vacuum. They operate in a politico-legal framework formed by international institutions and Member States. It is particularly the relationship with the latter that has raised concerns. Why would states voluntarily create international adjudicative bodies and submit to their jurisdiction? What means of control do they retain? Different models have been applied to capture this phenomenon. ${ }^{156}$ Proponents of the Principal-Agent theory, for example, posit that courts and tribunals are mere agents of their Member States, susceptible to political sanctions and threats thereof. The Member States can renegotiate the mandate of the courts or threaten to do so in order to ensure compliance with their own preferences. Others see courts as trustees of their Member States - independent but nevertheless subject to political influence. ${ }^{157}$ In particular, Member States might use 'rhetorical politics' to impact on a court's reasoning, they may delegitimize a court, or disband it altogether. Whereas Posner and Yoo consider the fragmentation of international courts as a consequence and proof of the states' desire to retain control, ${ }^{158}$ Slaughter and Helfer argue that international courts only enjoy 'constrained independence', meaning that they are formally independent but in fact controlled by their Member States through a 'range of structural, political, and discursive mechanisms'. ${ }^{159}$ Regardless of the label, it appears that a certain degree of political influence may often exist and should not be ignored.

This political influence risks undermining the contribution of international courts and tribunals to the rule of law. Independence and impartiality are the basic criteria for any court and tribunal that aspires to enjoy even a minimal degree of legitimacy, respect and confidence and to fulfil effectively the various roles with which it has been mandated. ${ }^{160}$ They are the sine qua non for any judicial contribution to the rule of law. ${ }^{161}$ Courts must be free from any form of external pressure - be it from the parties of the case, the states parties to the instrument establishing the

\footnotetext{
${ }^{154}$ Dworkin (n 120) 27.

155 Donald Regan, 'International Adjudication: A Response to Paulus - Courts, Custom, Treaties, Regimes, and the WTO' in Samantha Besson and John Tasioulas (eds) The Philosophy of International Law (OUP 2010) 227-229.

${ }^{156}$ See for an overview Ulfstein (n 20) 850 et seq.

${ }^{157}$ Karen J Alter, 'Agents or Trustees? International Courts in their Political Context' (2008) 14 European Journal of International Relations 33.

${ }^{158}$ Eric A Posner and John C. Yoo, 'Judicial Independence in International Tribunals' (2005) 93 California Law Review 1, 73.

159 Laurence R Helfer and Anne-Marie Slaughter, 'Why States Create International Tribunals: A Response to Professors Posner and Yoo' (2005) 93 California Law Review 899, 902.

${ }^{160}$ Gilbert Guillaume, 'De l'indépendance des membres de la cour international de justice' in Boutros Boutros-Ghali Amicorum Discipulorumque Liber: Paix, Développement, Démocratie (Vol 1, Bruylant 1998) 475; Gleider I Hernández, 'Impartiality and Bias at the International Court of Justice (2012) 1 Cambridge Journal of International and Comparative Law 183; Benvenisti and Downs (n 59) 1057.

161 Theodor Meron, 'Judicial Independence and Impartiality in International Criminal Tribunals' (2005) 99 American Journal of International Law 359; Lon Fuller, 'Adjudication and the Rule of Law' (1960) 54 Proceedings of the American Society of International Law 1, 2; Shelton (n 18) 545.
} 
court, the country hosting the seat of the court, or the international organization of which the court forms a part (independence). Judges need to base their decisions on the relevant facts and the applicable law, rather than on their own preferences (impartiality). ${ }^{162}$ These criteria constitute basic requirements for a court's effective contribution to the rule of law.

Independence and impartiality are values that need to be internalized by international judges and they must constantly guide their actions on the court. They need to 'reign the spirits and the hearts' of the judiciary. ${ }^{163}$ In addition, the institutional framework of the international adjudicative bodies needs to provide sufficient room for the exercise of the judicial function in line with these values, which particularly means that judges must be shielded from any form of external pressure. All of the statutes and rules of procedures of the selected courts ${ }^{164}$ contain safeguards to ensure the independence and impartiality of the respective judicial body. They provide for appointment procedures designed to ensure the independence of the judges from external influences, list the independence of the candidate as one of the basic eligibility criteria, they contain provisions on incompatibility, on the nationality of the judges, on their privileges and immunities, on their irremovability and remuneration, on the secrecy of deliberations and votes and lastly on the terms of office. The following subsections give a brief comparative overview of these formal safeguards.

\subsection{ELIGIBILITY CRITERIA}

The independence and impartiality of the candidate is an eligibility criterion that can be found in the governing texts of all selected courts and tribunals. ${ }^{165}$ Judges and Advocates General of the CJEU 'shall be chosen from persons whose independence is beyond doubt', ${ }^{166}$ the judges of the ICC and ICTY must distinguish themselves by their 'impartiality and integrity', ${ }^{167}$ the ICJ is to be 'composed of a body of independent judges'168 and the judges of the ITLOS are required to enjoy the 'highest reputation for fairness and integrity'. ${ }^{169}$ The Statute of the Special Tribunal for Lebanon is even more explicit on this issue. It provides not only that the judges be persons of 'impartiality and integrity', but also that they must be 'independent in the performance of their functions and shall not accept or seek instructions from any Government or any other source'. ${ }^{170}$ With respect to the ECtHR, Article 21(1) ECHR does not explicitly list the independence or impartiality of the judges as an eligibility criterion, and only refers to their 'high moral character'. Nevertheless, Article 21(3) ECHR obliges judges to refrain from 'any activity which is incompatible with their independence [or] impartiality'. Finally, the Members of the WTO AB are required by the Rules of Conduct to be 'independent and impartial' and to 'avoid direct or

\footnotetext{
162 Hernández (n 160) 184, 188 et seq.

${ }^{163}$ Ibid. For a critical view of the independence of international judges, see Vitalius Tumonis, 'Adjudication Fallacies: The Role of International Courts in Interstate Dispute Settlement' (2014) 31 Wisconsin International Law Journal 35 , 44 et seq.

164 See supra (n 31).

${ }^{165}$ See supra (n 31).

${ }^{166}$ Art 19(2), second subpara TEU and Arts 253-254 and 257 of the Treaty on the Functioning of the European Union (TFEU) (Consolidated Version of the Treaty on the Functioning of the European Union [2012] OJ C326/47).

${ }^{167}$ Art 36(3(a) Rome Statute of the International Criminal Court (adopted 17 July 1998, entered into force 1 July 2002) (ICC Statute), and art 13 ICTY Statute, respectively.

${ }^{168}$ Art 2 ICJ Statute.

${ }^{169}$ Art 2(1) Statute of the International Tribunal for the Law of the Sea, Annex VI of the United Nations Convention on the Law of the Sea (adopted 10 December 1982, entered into force 16 November 1994) (ITLOS Statute).

${ }^{170}$ Art 9(1) Statute of the Special Tribunal for Lebanon, UNSC Res 1757 (2007) UN Doc S/RES/1757 (STL Statute).
} 
indirect conflicts of interest'. ${ }^{171}$ All of these provisions are kept in general terms and do not specify what these criteria imply. More detailed guidance is usually provided in the subsequent provisions of the governing texts. Nevertheless, the consistent inclusion of independence and impartiality in the eligibility criteria underlines their fundamental value for the international judiciary and ensures their central importance for the election process.

\subsection{APPOINTMENT PROCEDURE}

The appointment procedures for most of the selected courts and tribunals ${ }^{172}$ are designed in order to avoid undue dominance by one state or group of states. Safeguards include the establishment of independent national nomination bodies or panels, the involvement of multiple organs in the election process, and the requirement of a high quorum. Candidates for the ICJ, for example, need to be nominated by the PCA national groups, a group of up to four individuals, which are appointed by the parties of the PCA to serve as potential arbitrators. ${ }^{173}$ In theory, the PCA national groups are supposed to be independent from their national governments. ${ }^{174}$ However, in practice it is not uncommon to find active government officials among them, ${ }^{175}$ and it has been argued that the majority of these groups are in fact 'extensions of their governments'. ${ }^{176}$ The CJEU and the ECtHR both have the safeguard of an independent nominations commission, which assesses the suitability of the candidates and delivers an opinion to the Member States before they proceed with the appointment. The panel for the CJEU is composed of former judges of the CJEU or the General Court, members of national supreme courts, and 'lawyers of recognised competence'. ${ }^{177}$ The composition of the ECtHR Advisory Panel is similar, but allows for the appointment of former judges of international courts more generally. These non-state selection committees may be more efficient in curtailing national influence on the nomination process. ${ }^{178}$

While judges of the ECtHR are selected by a simple majority in the Parliamentary Assembly of the Council of Europe, ${ }^{179}$ the ICC Statute requires a two-thirds majority of the States Parties present and voting, ${ }^{180}$ similar to the ITLOS Statute, where the quorum is a 'two-thirds majority of the States Parties present and voting, provided that such majority includes a majority of the

\footnotetext{
${ }^{171}$ Section II(1) Rules of Conduct for the Understanding on Rules and Procedures Governing the Settlement of Disputes, WTO Doc WT/DSB/RC/1.

172 See supra (n 31).

${ }^{173}$ Art 4(2) ICJ Statute. Note, that the PCA national groups also play an important role in the ICC nomination process, where candidates must be nominated either ' $[\mathrm{b}] \mathrm{y}$ the procedure for the nomination of candidates for appointment to the highest judicial offices in the State in question' or in line with the ICJ nomination procedure: art 36(4) ICC Statute.

${ }^{174}$ Ruth Mackenzie, Kate Malleson, Penny Martin and Philippe Sands, Selecting International Judges : Principle, Process, and Politics (OUP 2010) 69 et seq.

175 ibid 70.

176 Davis R Robinson, 'The Role of Politics in the Election and the Work of Judges of the International Court of Justice' (2003) 97 American Society of International Law Proceedings 277, 279; see also Mackenzie, Malleson, Martin and Sands (n 174) 145.

${ }^{177}$ Art 255 TFEU.

${ }^{178}$ Resolution CM/Res(2010)26 on the establishment of an Advisory Panel of Experts on Candidates for Election as Judge to the European Court of Human Rights (adopted 10 November 2010). For an analysis of the politicization of the appointment process at the ECtHR before the establishment of the Advisory Panel see Erik Voeten, 'The Politics of International Judicial Appointments: Evidence from the European Court of Human Rights' (2007) 61 International Organization 669 .

${ }^{179}$ Art 22 Convention for the Protection of Human Rights and Fundamental Freedoms, adopted on 4 November 1950, entered into force on 3 September 1953, ETS 5; 213 UNTS 221 (ECHR).

${ }^{180}$ Art 36(6)(a) ICC Statute.
} 
States Parties'. ${ }^{181}$ ICJ judges need to be elected in both the UN Security Council and the UN General Assembly, by an absolute majority in both organs. ${ }^{182}$ The involvement of both organs is also required by the ICTY Statute. Here, the UN Security Council creates a list of candidates based on nominations of the UN Member States and observers, from which the UN General Assembly will then elect the permanent judges with an 'absolute majority of the votes of the States Members of the United Nations and of the non-member States maintaining permanent observer missions at United Nations Headquarters'. ${ }^{183}$ Rather than by a majority vote, the judges of the CJEU are appointed 'by common accord' of all EU Member States. ${ }^{184}$ The only appointment procedure not involving elections is the one of the Special Tribunal for Lebanon, where the judges are appointed by the UN Secretary General ${ }^{185}$ following consultations with the Lebanese government and the recommendation of a selection panel. ${ }^{186}$ Lastly, the independence and impartiality of the members of the IUSCT is safeguarded by a procedure that reflects the character of the bilateral claims tribunal. Each government appoints one third of the members; the remaining third is selected by mutual agreement by the state-appointed members. ${ }^{187}$ While the selection process thus differs from court to court, most procedures display distinct democratic features and a strong merit-based approach. In all cases, the appointment procedure is designed in a way that aims to prohibit the dominance of one state or a group of states. However, whether these safeguards always achieve the intended results remains contested. Some have concluded that the election processes make it impossible for any state to exercise undue influence. ${ }^{188}$ Others have recognized the efforts 'on paper ... to reduce the effect of raw politics on the election process' while pointing out the 'reality of power politics', which ensures for example at the ICJ that the permanent members of the UN Security Council always have a national on the bench. ${ }^{189}$

\subsection{INCOMPATIBILITY}

The governing texts of most of the selected tribunals ${ }^{190}$ contain specific provisions on incompatibilities. Absolute incompatibility thereby refers to functions that are incompatible with the position of a judge per se, while relative incompatibility refers to the ability of a judge to hear a particular case.

The strictest rule is contained in the ICJ Statute which prohibits judges to exercise 'any political or administrative function, or engage in any other occupation of a professional nature, ${ }^{191}$ and to 'act as agent, counsel or advocate in any case'. ${ }^{192}$ The corresponding provision in the PCIJ Statute had been interpreted more leniently, as the Court's limited workload often allowed

\footnotetext{
${ }^{181}$ Art 4(4) ITLOS Statute.

${ }^{182}$ Art 10(1) ICJ Statute.

${ }^{183}$ Art 13 bis(1) ICTY Statute.

${ }^{184}$ Art 253 TFEU.

${ }^{185}$ Art 2(5)(a)-(b) STL Agreement; art 9(3) STL Statute.

${ }^{186}$ Art 2(5)(c)-(d) STL Agreement. of Iran (19 January 1981). system has 'overall ... proved itself'.

${ }^{189}$ Robinson (n 176) 278 et seq.

${ }^{190}$ See supra (n 31).

${ }^{191}$ Art 16(1) ICJ Statute.

${ }^{192}$ Art 17(1) ICJ Statute. For more detail see Kolb (n 188) 133-134; Guillaume (n 160) 475.
}

187 Art III(1) Declaration of the Government of the Democratic and Popular Republic of Algeria Concerning the Settlement of Claims by the Government of the United States of America and the Government of the Islamic Republic

${ }^{188}$ Alter (n 157) 46; for a careful assessment of the ICJ appointment process see Robert Kolb, The International Court of Justice (Hart 2013) 140, who states that politicization cannot always be excluded but concludes that the 
judges to pursue other activities on the side. An activity was not permissible 'if it interfered, even lightly or only potentially, with a judge's independence or impartiality', the mere semblance of incompatibility being sufficient to assume impermissibility. ${ }^{193}$ The increased workload of the ICJ has restricted the possibility of judges to engage in additional activities, which today leaves occasional appointments as an arbitrator or academic work as the only two options generally accepted by the ICJ. ${ }^{194}$ In a similar manner, the Statute of the CJEU provides that ' $\mathrm{t}$ ] $\mathrm{C}$. Judges may not hold any political or administrative office', and that they 'may not engage in any occupation, whether gainful or not, unless exemption is exceptionally granted by the Council, acting by a simple majority'. ${ }^{195}$

The ECHR makes the nexus between the absolute incompatibility of activities and the requirements of independence and impartiality more explicitly. It generally provides in Article $21(3)$ that '[d]uring their term of office the judges shall not engage in any activity which is incompatible with their independence, impartiality or with the demands of a full-time office...' 196 Judges need to be transparent about their activities outside the court and any disagreements are to be decided by the plenary. Similarly, the ITLOS Statute provides that no member of the tribunal may exercise 'any political or administrative function', 'associate actively with or be financially interested' in enterprises who explore, exploit or otherwise commercially use the sea or the seabed', or act as agent, counsel or advocate in any case'. ${ }^{197}$

The ICC Statute not only prohibits for the judges of the ICC any 'activity which is likely to interfere with their judicial functions or to affect confidence in their independence', it also prohibits any other 'occupation of a professional nature'. ${ }^{198}$ Conversely, persons serving on the WTO AB may engage in other professional activities, provided that they are 'unaffiliated with any government' and do 'not participate in the consideration of any disputes that would create a direct or indirect conflict of interest'. ${ }^{199}$

Most instruments also contain provisions on relative incompatibility in order to avoid conflicts of interest in specific cases. Incompatibilities are usually assumed if the judge (1) has personal interests in the case (for example family or professional ties with the parties), (2) has previously been involved in the case (for example as an agent, advocate, adviser or judge on another tribunal), (3) pursues political, administrative or professional activities incompatible with his independence and impartiality, or (4) publicly expressed his opinion on the case. ${ }^{200}$

\footnotetext{
${ }^{193}$ Kolb (n 188) 133.

194 ibid 134.

${ }^{195}$ Art 4 Protocol (No 3) on the Statute of the Court of Justice of the European Union [2012] OJ C 326/210 (CJEU Statute). Pursuant to art 8, the same rules apply to the Advocates General.

${ }^{196}$ See also Rule 4 of the Rules of Procedure of the Court, which provides that judges shall not 'engage in any political or administrative activity or any professional activity which is incompatible with their independence or impartiality or with the demands of a full-time office'.

${ }^{197}$ Art 7ITLOS Statute.

${ }^{198}$ Art 40ICC Statute.

${ }^{199}$ Art 17 Understanding on Rules and Procedures Governing the Settlement of Disputes, Annex 2 of the Agreement establishing the World Trade Organisation (signed 15 April 1994, entered into force 1 January 1995) (WTO DSU).

200 See e.g. rule 28 ECtHR Rules of Court (1 July 2014); art 41(2)(a) ICC Statute; art 17(2) ICJ Statute; art 8 ITLOS Statute; rule 25 Rules of Procedure and Evidence of the Special Tribunal for Lebanon (adopted 20 March 2009, in the version of 3 April 2014); see also art 9-12 IUSCT Rules of Procedure (3 May 1983).
} 


\subsection{NATIONALITY}

Several instruments contain provisions governing the situation that a judge and a party share the same nationality. The ICJ Statute and the ITLOS Statute, for example, explicitly provide that the judges/members of the nationality of any party retain their right to hear the case. ${ }^{201}$ In these cases, the other party may choose an ad hoc judge to sit on the respective case. Ad hoc judges may also be appointed in cases where neither of the parties has a judge of its own nationality on the bench. The possibility to appoint ad hoc judges therefore aims to bring relevant expertise to the bench and to increase the court's legitimacy, while also ensuring equality between the parties. ${ }^{202}$ However, both the Rules of the Procedure of the ECtHR and of the ITLOS stipulate that the Presidency may not be exercised by a national of any party in a given case ${ }^{203}$ Even though studies have found little evidence for the assumption that judges are generally more favourable towards the positions of their home country, ${ }^{204}$ these rules contribute to the external perception of an impartial and balanced body, in line with the maxim that 'justice must not only be done, but be seen to be done'. ${ }^{205}$ Nationality continues to play an important role with regard to the composition of the bench, as evidenced by the efforts to ensure a geographic balance, but also by the insistence of the permanent members of the UN Security Council each to have a national on the ICJ. ${ }^{206}$

\subsection{PRIVILEGES AND IMMUNITIES}

An essential safeguard for the independence of a judge is the granting of privileges and immunities, which guarantees the judge the necessary freedom to fulfil his functions. In particular, it avoids pressure through politically motivated prosecutions. Most governing texts of the selected courts and tribunals ${ }^{207}$ contain provisions in this respect. ${ }^{208}$ While the majority of these provisions only grant immunity during the exercise of the judicial function, the CJEU Statute and the ICC Statute also grant immunity after a judge has left the court with respect to legal proceedings on any acts performed in the judicial capacity. ${ }^{209}$

\subsection{IRREMOVIBILITY}

Another essential tool to ensure the independence of the judges is their irremovibility from the bench during the period of their mandate. As for example the ICJ Statute provides: 'No member of the Court can be dismissed unless, in the unanimous opinion of the other members, he has ceased to fulfil the required conditions' ${ }^{210}$ Similar provisions can be found for example in the statutes of the CJEU, the ECtHR, the ICC and the ITLOS. ${ }^{211}$ They are intended to serve as

\footnotetext{
${ }^{201}$ Art 31 ICJ Statute; art 17(1) ITLOS Statute.

${ }^{202}$ Kolb (n 188) 118 et seq.; Leigh Swigart, 'The "National Judge": Some Reflections on Diversity in International Courts and Tribunals' (2010) 42 McGeorge Law Review 223, 227 et seq.

${ }^{203}$ Rule 24(5)(c) ECtHR Rules of Court; art 16 ITLOS Rules of the Tribunal (17 March 2009).

204 This applies in the first line to permanent judges. Ad hoc judges have evidenced a tendency to vote in favour of the country that appointed them. See Guillaume ( $n$ 160) 486 fn 8 for references to studies on the link between nationality and independence; see also Hernández (n 160) 185.

${ }^{205}$ Kolb (n 188) 133.

${ }^{206}$ See subsection 5.2 above.

207 See supra (n 31).

${ }^{208}$ See art 3 CJEU Statute, which pursuant to art 8 also applies to Advocates General; art 51 ECHR; art 48 ICC Statute; art 19 ICJ Statute; art 30 ICTY Statute; art 10 ITLOS Statute; art 11 STL Agreement.

${ }^{209}$ Art 3 CJEU Statute, which pursuant to art 8 also applies to Advocates General; art 48(2) ICC Statute.

${ }^{210}$ Art 18 ICJ Statute.

${ }^{211}$ Art 6 CJEU Statute, which pursuant to art 8 also applies to Advocates General (unanimity of Judges and Advocates General required); art 23(4) ECHR (two-thirds majority of the other judges required); art 46 ICC Statute
} 
safeguards against political interference with the work of the court through the threat of dismissal of its members.

\subsection{REMUNERATION}

A similar motivation underlies a provision that can be found in statutes of several selected courts. $^{212}$ In order to limit the scope of potential political pressure that may be exercised on the judges, these provisions stipulate that the salaries, allowances and compensation of the judges may not be decreased during their term of office. ${ }^{213}$ Judges can therefore not be threatened with financial sanctions in order to ensure a certain voting behaviour.

\subsection{SECRECY OF DELIBERATIONS AND VOTING}

It has been argued that 'in all judicial activity, the secrecy of deliberations serves as an essential guarantee of the judge's independence'. ${ }^{214}$ However, this principle is interpreted differently across the various legal cultures of the world. Whereas judicial deliberations and votes are usually confidential in the continental European tradition, common law countries are more familiar with the disclosure of the votes and the publication of separate (dissenting and concurring) opinions. The practice at the level of the international judiciary is uneven. Nevertheless, there are certain commonalities.

All governing texts of the selected courts and tribunals ${ }^{215}$ protect the confidentiality of the judges' deliberations, which 'shall take place in private and remain secret'. ${ }^{216}$ Most courts and tribunals also protect the secrecy of voting. The ICJ and ITLOS form an exception in this respect. Article 125(1)(I) of the ITLOS Rules states that the judgment shall contain 'the number and names of the judges constituting the majority and those constituting the minority, on each operative provision'. The ICJ Statute was originally silent on this issue. Until 1978, the ICJ rejected the publication of the voting behaviour, considering such a practice to be 'against the Statute itself.'. ${ }^{217}$ At the same time, however, judges were free to deliver separate opinions (dissenting or concurring), thus rendering the attempt to ensure secrecy rather futile. In 1978, the ICJ's Rules of Procedure were amended and now list 'the number and names of the judges constituting the majority' among the elements that need to be contained in a judgment. ${ }^{218}$ The same issue can be observed with regard to most other international courts and tribunals. While for example the ECtHR, the three criminal courts and the IUSCT do not provide the names of the judges voting in favour or against a decision, they all permit the publication of separate opinions, thus allowing for inferences to be drawn on the voting behaviour. ${ }^{219}$ The CJEU is the only court that maintains the principle of 'apparent unanimity' in line with the domestic legal

(two-thirds majority of the States Parties following a recommendation adopted by two thirds of the other judges); art 9 ITLOS Statute (unanimity of the other members of the Tribunal required).

212 See supra (n 31).

${ }^{213}$ See e.g. art 49 ICC Statute; art 32(5) ICJ Statute; art 18(5) ITLOS Statute.

${ }^{214}$ Guillaume (n 160) 484.

215 See supra (n 31).

${ }^{216}$ Art 54(3)ICJ Statute; see also art 35 CJEU Statute; rule 22 ECtHR Rules of Court; art 74(4) ICC Statute; rule 29, 87 ICTY Rules of Procedure and Evidence; note to art 31 IUSCT Rules of Procedure; art 42(1) ITLOS Rules of the Tribunal; rule 43, 148 STL Rules of Procedure and Evidence; arts 14, 17 WTO DSU.

${ }^{217}$ Guillaume (n 160) 485.

${ }^{218}$ Art 95 ICJ Rules of Court; see also art 107 ICJ Rules of Court for Advisory Opinions.

${ }^{219}$ Rule 74(1)(k) and 74(2) ECtHR Rules of Court; art 74(5) ICC Statute; art 23(2) ICTY Statute; art 32 IUSCT Rules of Procedure; art 23 STL Statute. 
traditions of its founding Member States: ${ }^{220}$ deliberations and votes are kept secret, and no separate opinions are published. Aside from domestic legal traditions, fear of individual judges either always defending their home state's position or, conversely, declining to do so and hence being refused an additional term by their home Member State, as well as the concern that dissenting opinions may undermine the authority of the Court, are often cited as the main reasons why allowing separate opinions was not considered apposite. ${ }^{221}$ Finally, the WTO Dispute Settlement System aims for a compromise approach. Panel or AB members may publish separate opinions, but they must be anonymous. ${ }^{222}$ However, critics have argued that this attempt to safeguard the independence of the panel or $A B$ members is in practice not very effective, given that the name of the dissenter will often be easily identified by those familiar with the case. ${ }^{223}$

The picture is therefore mixed, ranging from complete confidentiality of the judges' deliberations and votes to disclosure of voting behaviour and publication of separate opinions. This can have implications for the degree of outside pressure that a judge may receive or perceive.

\subsection{TERM OF OFFICE}

Schermers and Blokker identify the length of the term of office as a safeguard for judicial independence in the sense that a longer term equals more independence. ${ }^{224}$ In contrast to judges on national courts, international judges are as a rule not appointed for life or until retirement but for limited periods of time, and may or may not be reappointed, depending on the institutional framework. This practice was established with the first international courts and tribunals in the beginning of the twentieth century ${ }^{225}$ and maintained in the Statute of the PCIJ. The Advisory Committee of Jurists, which drafted the PCIJ's Statute, considered a proposal by Sweden to appoint the judges of the PCIJ for life but opted for a term of nine years with the possibility of re-election instead. It reasoned that the term should be long enough to create an 'esprit de corps', that re-election should be possible in order to reward 'faithful and efficient service' but that judges should not be appointed for life in order to preserve the possibility to replace those judges who 'failed to justify their election'. ${ }^{226}$ With the exception of the IUSCT, ${ }^{227}$

\footnotetext{
${ }^{220}$ Rosa Raffaelli, 'Dissenting opinions in the Supreme Courts of the Member States', Study for the European Parliament, Directorate General for Internal Policies, Policy Department C: Citizens' Rights and Constitutional Affairs, PE 462.470, 2012, 33.

${ }^{221}$ See Geert De Baere, 'Aboli bibelot d'inanité sonore?' (2008) 33 EL Rev 935; further: Anthony Arnull, The European Union and its Court of Justice (2nd edn OUP 2006) 11.

${ }^{222}$ Arts 14 and 17 WTO DSU. Separate opinions in the WTO Dispute Settlement System are very rare. See for example Meredith Kolsky Lewis, 'The Lack of Dissent in WTO Dispute Settlement' (2006) 9 Journal of International Economic Law 895. See also <www.wto.org/english/res_e/booksp_e/analytic_index_e/dsu_06_e.htm\#article14 > for a list of individual opinions in panel reports and $<$ www.wto.org/english/res_e/booksp_e/analytic_index_e/dsu_07_e.htm> for a list of concurring and separate opinions in the WTO AB reports (until 30 September 2011). For a recent noteworthy example, see the dissenting opinion in China - Measures Related to the Exportation of Rare Earths, Tungsten and Molybdenum - Reports of the Panel, WT/DS432/R.

${ }^{223}$ Raffaelli (n 220) 33

${ }^{224}$ Schermers and Blokker (n 5) 486 et seq., para 683.

${ }^{225}$ This includes established and proposed courts, namely the Central American Court of Justice (five years, reelection possible), International Prize Court (six years), Court of Arbitral Justice (12 years, re-election possible), see John Dugard in Andreas Zimmermann, Karin Oellers-Frahm, Christian Tomuschat and Christian J Tams (eds) The Statute of the International Court of Justice: A Commentary (2nd ed, OUP 2012) art 13 no 2. ${ }^{226}$ Ibid.
} 
the selected courts and tribunals ${ }^{228}$ all follow this model. The length of the terms of office range from nine years (ICJ, ITLOS, ECtHR and ICC) to six (CJEU), four (WTO AB, ICTY) and three years (Special Tribunal for Lebanon). ${ }^{229}$ Re-election is permitted by all courts except for the ECtHR and the ICC. The WTO AB limits the number of re-elections to one.

This practice appears to have been widely accepted. It should however not be overlooked, that the fixed-term mandates of judges and the possibility of re-election may negatively impact on the independence and impartiality of judges. First, the opportunity of re-election can create incentives for judges to avoid decisions that might run contrary to the positions of influential Member States. ${ }^{230}$ The mere existence of such incentive can be enough to cast doubt on their independence and impartiality, even if it does not in fact influence the motivation of the judge. Second, the re-election process provides a possibility for states to sanction unwelcome actions and thus to exercise political pressure. ${ }^{231}$

It would therefore arguably be more conducive to the independence and impartiality of the judges if international courts and tribunals opted for non-renewable long-term mandates instead of the current practice. ${ }^{232}$ The solution adopted in the ECtHR could be considered a best practice in that regard.

\subsection{INTERIM CONCLUSIONS}

The selected courts and tribunals ${ }^{233}$ have been equipped with a range of safeguards against most forms of political interference. Nevertheless, it is doubtful whether these formal institutional rules can ever be sufficient. In the end, the Member States retain control over the delegated powers of the international court or tribunal and they can sanction the judicial body by renegotiating the foundational instrument on which the court or tribunal is based - even if that may only be a 'nuclear option'. ${ }^{234}$ It is therefore important always to consider the broader politico-legal context in which international courts and tribunals operate. Besides all formal safeguards and the personal integrity of the judges, a high degree of intra- and interstate political competition between the courts' States, as well as a high degree of discrepancy in their policies remains the most important safeguard of a court's independence. ${ }^{235}$ It is beyond the scope of this paper to assess the various political forces that influence the different courts and tribunals. ${ }^{236}$ Nevertheless, the broader politico-legal framework must not be overlooked when dealing with the question of international judicial independence.

\footnotetext{
227 IUSCT members are appointed for 'the course of the arbitral proceedings', but provision is made for their challenge and/or replacement pursuant to arts 9-13 IUSCT Rules of Procedure.

${ }^{228}$ See supra (n 31).

${ }^{229}$ Art 253 TFEU (six years); art 23 ECHR (nine years); art 36(9)(a)ICC Statute (nine years); art 13 ICJ Statute (nine years); art 13bis (3) ICTY Statute (four years); art 5(1) ITLOS Statute (nine years); art 9(3) STL Statute (three years); art 17(2) WTO DSU (four years).

${ }^{230}$ Meron (n 161) 362.

${ }^{231}$ Kolb (n 188) 112.

${ }^{232}$ See also Meron (n 161) 362.

233 See supra (n 31).

${ }^{234}$ Alter (n 157) 44; See for example the case of the Southern African Development Community (SADC) Tribunal which was sanctioned, first by a blockade of the elections of judges, then by a restriction of its jurisdiction: Romano ( $\mathrm{n}$ 44) 123.

${ }^{235}$ See Benvenisti and Downs (n 59) 1059.

${ }^{236}$ See supra (n 31).
} 


\section{AN OVERVIEW OF THE CONTRIBUTION OF INTERNATIONAL AND SUPRANATIONAL COURTS TO THE RULE OF LAW}

This paper adopted as a working assumption that, at its most basic, the rule of law can be described as a principle that all individuals and entities, including states and international organizations, are to be subject to and accountable to the law. That implies the subjection of individuals and all levels of public power in the national and international realm to legal constraints with a view to guaranteeing the equal protection of all individuals against its arbitrary or unlawful use of power. ${ }^{237}$

As explored above, international courts no longer solely fulfil the role of dispute settlers, but have taken on new functions. ${ }^{238}$ Alter lists criminal enforcement and infringement proceedings, dispute resolution as well as administrative and constitutional review as the four ideal types of judicial functions. Von Bogdandy and Venzke additionally consider the international judiciary to have a law-making function ${ }^{239}$, while Shelton adds the provision of 'legal advice'. ${ }^{240}$ Arguably, therefore, international and supranational courts can contribute to the rule of law through dispute settlement (6.1) and compliance assessment (6.2), the tackling of impunity (6.3), as well as through the clarification and development of international law (6.4). These (partially overlapping) functions may be considered direct contributions. Indirectly, international courts may, by fulfilling these functions, contribute to the socialization of states to the concept of the rule of law at the international level and to its growing importance in international relations. ${ }^{241}$

\subsection{DISPUTE SETTLEMENT}

Dispute settlement is the traditional domain of international courts and also the role that most of the selected international courts and tribunals ${ }^{242}$ have been allocated by their Member States. By peacefully settling disputes on the basis of law, the adjudicator ideally takes away sources of tension between the parties and ensures that it is not political or economic power that decides over the outcome of a dispute, but the law ('right over might'), thereby avoiding arbitrariness and contributing to the equal protection of individuals.

Dispute settlement is the core competence of the ICJ, the ITLOS, the WTO Dispute Settlement System and the IUSCT. The ICJ is explicitly mandated with the settlement of disputes ${ }^{243}$, and has at the time of writing rendered 116 judgments, ${ }^{244}$ the majority of which since the $1990 \mathrm{~s}$. Similarly, the ITLOS has been tasked to 'deal with disputes arising out of the Convention'. ${ }^{245}$ So far, 22 contentious cases have been submitted to the Tribunal. However, both courts have received far less cases than the WTO Dispute Settlement System, which - with 188 panel reports and 110 appellate reports - is the most prolific state-to-state dispute settlement body. ${ }^{246}$ The 'prompt settlement' of disputes is the principal objective of the WTO Dispute Settlement System and considered 'essential to the functioning of the WTO' ${ }^{247}$ Conversely, the IUSCT

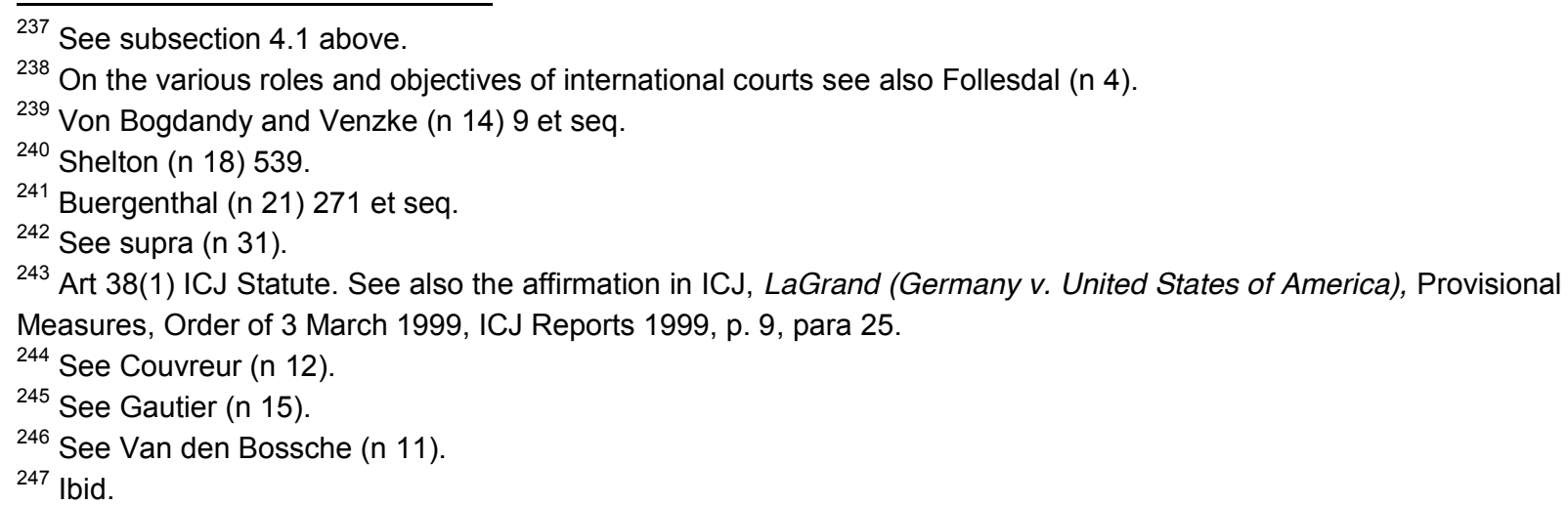


does not only have jurisdiction over state-to-state disputes (contractual claims of the United States and Iran against each other) but also over claims of nationals of either state against the other. It has received a total of 3953 claims of which only 16 remain on the tribunal's docket today.

The increasing recourse to international dispute settlement might suggest that these international courts and tribunals enjoy legitimacy and inspire the necessary confidence that motivates parties to turn towards them for fair and just dispute settlement. ${ }^{248}$ The settlement of disputes by legal means can in itself be considered an important contribution to the rule of law. However, critics point to the fact that only a small percentage of international disputes make it onto the docket of an international court or tribunal ${ }^{249}$, particularly if the case touches upon politically sensitive issues. ${ }^{250}$ It has, for example, been argued that the ICJ has so far mostly dealt with rather uncontroversial cases on boundary delimitations and treaty interpretation. ${ }^{251}$ The majority of international disputes never make it to a judge's desk. Furthermore, it has been pointed out that dispute settlement before an international court or tribunal requires money and expertise, and may thus not be accessible to poorer countries. ${ }^{252}$ In particular, the judicialization of the WTO as opposed to the GATT regime and the disappearance of developing countries from the Dispute Settlement System's docket has been cited as illustrating the increasing hurdles these countries face. ${ }^{253}$ However, this is countered by Van den Bossche, who not only sees no disparity in terms of numbers between developed and developing countries in the WTO Dispute Settlement System ${ }^{254}$ but also refers to the Advisory Centre on WTO Law (ACWL), which provides low cost or pro bono legal services to developing country WTO Members. ${ }^{255}$

Through dispute settlement - their oldest and most uncontroversial ${ }^{256}$ function - international courts and tribunals make a significant contribution to the rule of law. Nevertheless, other functions, such as the clarification of international law and compliance assessment, may in the meantime have come to rival it in terms of importance.

\subsection{COMPLIANCE ASSESSMENT}

As mentioned above, compliance assessment is a primary tool to subject public power to the constraints of international law and to protect the rights of individuals. External compliance assessment entails the control exercised by international courts and tribunals over the acts of domestic authorities. Internal compliance assessment involves the judicial control over the acts of the international organisation of which they are organs. In that sense this paper uses the term 'compliance assessment' flexibly, encompassing Alter's categories of 'enforcement', 'administrative review' and 'constitutional review', ${ }^{257}$ in line with von Bogdandy's and Venzke's

\footnotetext{
${ }^{248}$ See also section 5 above.

249 José E Alvarez, 'The New Dispute Settlers: (Half) Truths and Consequences' (2003) 38 Texas International Law Journal 405, 411 et seq.

${ }^{250}$ Tumonis (n 163) 40.

${ }^{251}$ Ibid. See e.g. the Nicaragua case, in which the United States withdrew its acceptance of the ICJ's jurisdiction out of dissatisfaction with the Court: ICJ, Military and Paramilitary Activities in and against Nicaragua (Nicaragua v. United States of America), Jurisdiction and Admissibility, Judgment, ICJ Reports 1984, p. 392.

252 Ibid 47.

253 lbid 47 et seq.

${ }^{254}$ See Van den Bossche (n 11).

255 Ibid.

${ }^{256}$ The 'functional myopia' of scholarship to focus entirely or predominantly on dispute settlement is addressed in von Bogdandy and Venzke (n 14) 3.

257 Alter (n 18).
} 
concept of 'controlling and legitimating public authority'. ${ }^{258}$ Compliance assessment can thus be exercised by every international court and tribunal mandated to rule on the compliance of a public authority with international law. It can be exercised to different degrees: external compliance assessment is generally limited to declaring an action by public authorities noncompliant with international law or to awarding remedies, while internal compliance assessment may imply the authority to invalidate the non-compliant act.

Illustrative of external compliance assessment are the powers exercised by the ECtHR, the WTO Dispute Settlement System and the CJEU, when they review the compliance of domestic authorities with the ECHR, WTO Law or EU law. The ECtHR has been created to 'ensure the observance of the engagements undertaken by the High Contracting Parties in the Convention and the Protocols thereto'. ${ }^{259}$ Where it receives applications from States Parties ${ }^{260}$ or individuals ${ }^{261}$ alleging a breach of the applicable law, the Court may decide on whether or not a violation exists, and authorize remedies. Similarly, the WTO Dispute Settlement System receives applications from other WTO Members alleging violations of the WTO Agreements. The CJEU has jurisdiction with respect to actions brought against a Member State for its failure to fulfil its obligations under the Treaties pursuant Articles 258-260 TFEU ('infringement proceedings'), as well as with respect to preliminary ruling procedures in relation to the interpretation of Union law under Article 267 TFEU, which indirectly concern the compatibility of national law with Union law. None of these bodies has the competence to invalidate a noncompliant domestic law. ${ }^{262}$

Illustrative of internal compliance assessment are the judicial review by the CJEU of acts or failures to act of the Union institutions. ${ }^{263}$ In that regard, the Court held in Les Verts that the Community, now the Union is, 'based on the rule of law, inasmuch as neither its Member States nor its institutions can avoid a review of the question whether the measures adopted by them are in conformity with the basic constitutional charter, the Treaty'. ${ }^{264}$ Nevertheless, international

\footnotetext{
${ }^{258}$ Von Bogdandy and Venzke (n 14) 11 et seq.

${ }^{259}$ Art 19 ECHR.

${ }^{260}$ Art 33 ECHR.

${ }^{261}$ Art 34 ECHR.

${ }^{262} \mathrm{Eg}$ as regards the CJEU, see with respect to infringement proceedings ECJ, Opinion of Advocate General Reischl in France $v$ UK, 141/78, EU:C:1979:202, p. 2946; and with respect to references for a preliminary ruling ECJ, judgment in Azienda Agro-Zootecnica Franchini and Eolica di Altamura, C-2/10, EU:C:2011:502, para 35, recalling settled case law holding that 'although the Court does not, in a reference for a preliminary ruling, have jurisdiction to give a ruling on the compatibility of a national measure with European Union law, it does have jurisdiction to supply the national court with a ruling on the interpretation of European Union law so as to enable that court to determine whether such compatibility exists in order to decide the case before it'. See also ECJ, judgment in Ministero delle Finanze $v$ IN.CO.GE.'90 and Others, C-10/97 to C-22/97, EU:C:1998:498, para 21, holding that it could not be inferred from ECJ, judgment in Amministrazione delle finanze dello Stato v Simmenthal, 106/77, EU:C:1978:49 'that the incompatibility with Community law of a subsequently adopted rule of national law has the effect of rendering that rule of national law non-existent. Faced with such a situation, the national court is, however, obliged to disapply that rule....'

${ }^{263}$ The CJEU can exercise that review through the action for annulment under art 263 TFEU; the action for failure to act under art 265 TFEU; the objection of illegality under art 277 TFEU; preliminary rulings on the validity of Union acts under art 267 TFEU; the action for damages against the Union under arts 268 and 340(2) TFEU; and the application for an opinion on the compatibility of an international agreement to be concluded by the Union with the provisions of the Treaties under art 218(11) TFEU.

${ }^{264}$ ECJ, judgment in Parti écologiste 'Les Verts'v European Parliament, 294/83, EU:C:1986:166, para 23. See further Lenaerts (n 116).
} 
courts or tribunals typically lack jurisdiction to adjudicate issues concerning the conduct of the organisations of which they are a part. ${ }^{265}$ The WTO AB is a clear example of that phenomenon. ${ }^{266}$ Furthermore, it remains contested whether the ICJ has any jurisdiction to review the legality of UN Security Council resolutions. ${ }^{267}$ The issue was raised in the context of the Lockerbie case, which was withdrawn before the ICJ could render its final decision on the matter. ${ }^{268}$

While the contributions of the international judiciary to the rule of law are remarkable in this respect, it is also apparent that the rule of law is still weaker at the international level than at the regional and national level. There is a considerable lower degree of judicial control exercised over the activities of international actors, resulting in a comparatively weaker system of checks and balances.

\subsection{TACKLING OF IMPUNITY}

As argued above, the rule of law requires that legal constraints bind not only all levels of public power but also individuals. Consequently, individuals who violate international norms that prohibit gross human rights violations, need to be held accountable for their actions. In this respect, the international criminal tribunals have contributed to the rule of law by 'reassert[ing] the vital truth that every person, at every level of seniority and influence, is subject to [the] law'. ${ }^{269}$ Since its establishment, the ICTY has indicted 161 people for serious violations of international humanitarian law committed in the territory of the former Yugoslavia, of which 141 were either sentenced, acquitted, referred or had their proceedings terminated in another way. ${ }^{270}$ The ICC currently conducts proceedings on 21 cases resulting from eight situations (Central African Republic, Cote d'Ivoire, Darfur (Sudan), Democratic Republic of the Congo, Kenya, Libya, Mali and Uganda). ${ }^{271}$

These numbers, although illustrative of the courts' high workload, are vanishingly small when compared to the number of international crimes committed around the globe. The currently existing international criminal judicial bodies not only lack the jurisdiction but also the resources to address them. They are ill-equipped to make more than a marginal contribution to ending

\footnotetext{
${ }^{265}$ Kingsbury (n 133) 211.

266 Ibid.

${ }^{267}$ Higgins (n 23).

${ }^{268}$ See nevertheless the dissenting opinion of President Schwebel in ICJ, Questions of Interpretation and Application of the 1971 Montreal Convention arising from the Aerial Incident at Lockerbie (Libyan Arab Jamahiriya $v$ United States of America), Preliminary Objections, Judgment, ICJ Reports 1998, p 115, concluding from the travaux préparatoires (especially the episode of the failed Belgian proposal to introduce a limited possibility of review by the ICJ) that the ICJ was not and was not meant to be invested with a power of judicial review of decisions of the Security Council (dissenting opinion of President Schwebel, 171). Further: Bernd Martenczuk, 'The Security Council, the International Court and Judicial Review: What Lessons from Lockerbie?' (1999) 10 European Journal of International Law 517.

${ }^{269}$ See Serge Brammertz, 'International criminal justice and the rule of law: the experience of the International Criminal Tribunal for the Former Yugoslavia (ICTY)' in Geert De Baere and Jan Wouters (eds), The Contribution of International and Supranational Courts to the Rule of Law (Edward Elgar, forthcoming).

${ }^{270}$ ICTY, 'Key Figures of the Cases', available at <http://www.icty.org/sections/TheCases/KeyFiguresoftheCases>.

271 ICC, 'Report of the International Criminal Court on its activities in 2013/14' (18 September 2014) UN Doc $\mathrm{A} / 69 / 321$.
} 
impunity. Instead, they need to strengthen domestic accountability mechanisms ${ }^{272}$ and be selective about their cases. As Brammertz explains, the ICTY adopted a combined 'top down' and 'bottom up' approach - targeting lower-level perpetrators in the start-up phase of the tribunal and moving onto more high level perpetrators once the tribunal's expertise and its political support had increased. ${ }^{273}$ In addition, a balance needed to be found between comprehensive indictments, which would cover all crimes a perpetrator was believed to be responsible for, and practical considerations, particularly concerning the duration of the trial. ${ }^{274}$

The contribution of international criminal courts and tribunals to tackling impunity - though important in those cases that actually make it onto the docket - must for the time being remain limited. At the same time, the focus on international criminal law as it is now also points to some of the remaining gaps in the rule of law at the international level. First, to the present day, only individuals are subject to the constraints of criminal law at the international level. Other international actors, such as multinational corporations, do not fall under the jurisdiction ratione personae of any international criminal court. Second, with the exception of EU law and international criminal law, international law as a rule does not contain binding obligations for other than state actors. This has been considered unsatisfactory in particular with regard to human rights law, in light of widespread human rights abuses by natural and legal persons. Domestic instruments have often proven insufficient to hold accountable perpetrators who operate globally, and flexibly move across borders. ${ }^{275}$

Ending impunity consequently remains an elusive goal, despite the considerable merits of the international criminal judiciary. The subjection of individuals and legal persons to legal constraints is still an area where the international rule of law evidences considerable weaknesses.

\subsection{CLARIFICATION AND DEVELOPMENT OF INTERNATIONAL LAW}

The concept of the rule of law implies the existence of a set of legal constraints that guides and binds the behaviour of all individuals and all levels of public power. The legal rules need to be sufficiently clear in order to provide a reliable and predictable framework. In this respect, international courts and tribunals make an important contribution to the rule of law through their interpretation and clarification of international law. This contribution goes beyond the cases that are submitted to the courts and affects international law as a whole.

The ICJ, as the only universal international court with general jurisdiction, plays a central role in this respect. Its interpretations enjoy the highest respect and are frequently referred to in the case law of other courts and tribunals. ${ }^{276}$ As Couvreur has stated, its jurisprudence indisputably contributes to the establishment of a body of "precedents" regarding questions of general

\footnotetext{
${ }^{272}$ See Chan and Wouters 'Constructing the International Criminal Court's rule of law identity' in Geert De Baere and Jan Wouters (eds), The Contribution of International and Supranational Courts to the Rule of Law (Edward Elgar, forthcoming).

${ }^{273}$ See Brammertz (n 269).

274 Ibid.

${ }^{275}$ Jan Wouters and Anna-Luise Chané, 'Multinational Corporations in International Law' in Math Noortmann, August Reinisch and Cedrid Ryngaert (eds), Handbook on Non-State Actors (Hart 2015).

${ }^{276}$ Charney (n 23) 699, 705. For a recent example, see ECJ, judgment in Oberto and O'Leary, C-464/13 and C465/13, EU:C:2015:163, para 61, holding that 'as is clear from the case-law of the International Court of Justice, the subsequent practice followed in the application of a treaty may override the clear terms of that treaty if that practice reflects the parties' agreement (ICJ, Case concerning the Temple of Preah Vihear (Cambodia v Thailand), judgment of 15 June 1962, ICJ Reports 1962, p. 6)'.
} 
international law, the authority and significance of which extend far beyond the parties to a particular dispute'. ${ }^{277}$ It therefore plays a unifying role in international law, contributing to the coherence of this body of law and of the case law of other international judicial bodies. Areas in which the ICJ has particularly contributed to the clarification of international law include the law of state responsibility and the law of immunity. ${ }^{278}$

Article 3(2) DSU explicitly provides for the WTO Dispute Settlement System to be 'a central element in providing security and predictability to the multilateral trading system'. As the panel in United States - Sections 301-310 of the Trade Act of 1974 held: 'The security and predictability in question are of "the multilateral trading system". The multilateral trading system is, per force, composed not only of States but also, indeed mostly, of individual economic operators. The lack of security and predictability affects mostly these individual operators'. ${ }^{279}$ To that end, the Dispute Settlement System is mandated to 'clarify the existing provisions of those agreements in accordance with customary rules of interpretation of public international law'. ${ }^{280}$ Unlike other international courts and tribunals, the WTO Dispute Settlement System follows a primarily textual interpretation approach, giving central importance to the wording of the agreements. As Article 3(2) and 19(2) DSU provide, the WTO panels and AB may not 'add to or diminish the rights and obligations provided in the covered agreements'. In that regard, Van den Bossche argues that the high respect enjoyed by the WTO AB today is 'to a large extent due to the Appellate Body's choice for, and consistent application of, a 'text first' approach to interpretation'. ${ }^{281}$

In the field of international criminal law, the ICTY has made a significant contribution through its interpretation and clarification of the nascent legal regime, in particular concerning the modes of liability and elements of crime under customary international law. ${ }^{282}$ Its decisions have informed later case law by other international criminal tribunals and have strengthened legal certainty in international criminal law.

As a human rights court, the ECtHR sees its role not only in the provision of individual justice but also in the clarification of general human rights standards for the Member States of the Council of Europe. It has stated that 'its judgments serve not only to decide those cases brought before it but, more generally, to elucidate, safeguard and develop the rules instituted by the Convention, thereby contributing to the observance by the States of the engagements undertaken by them as Contracting Parties' ${ }^{283}$ The contribution of the ECtHR thus helps to clarify and strengthen the human rights system in Europe and ideally to decrease the need for judicial remedies.

While international courts and tribunals contribute to the growing body of precedents on international law with every decision rendered, some courts have additionally been provided

\footnotetext{
${ }^{277}$ See Couvreur (n 12). For a more critical assessment see Koskenniemi and Leino (n 23) 576.

${ }^{278}$ See Couvreur (n 12).

${ }^{279}$ WTO DSB Panel Report, United States - Sections 301-310 of the Trade Act of 1974, WT/DS152/R, adopted 22 December 1999, para 7.76

${ }^{280}$ Art 3(2) WTO DSU.

${ }^{281}$ See Van den Bossche (n 11). See further Isabelle Van Damme, Treaty Interpretation by the WTO Appellate Body (OUP 2009); and Isabelle Van Damme, 'The function of interpretation in the WTO' 21 (2010) European Journal of International Law 605-648.

${ }^{282}$ See Brammertz (n 269).

${ }^{283}$ ECtHR, Ireland $v$ the United Kingdom (1978) Series A no 25, para 154; ECtHR, Guzzardi v Italy (1980) Series A no 39, para 86; ECtHR, Karner v Austria ECHR 2003-IX, para 26; ECtHR, Konstantin Markin v Russia ECHR 2012III, para 89.
} 
with specific - non-contentious - procedures focused solely on providing legal interpretation. Two examples are illustrative in that regard. ${ }^{284}$

First, Article 96(a) of the UN Charter provides that the UN General Assembly and the UN Security Council may request the ICJ 'to give an advisory opinion on any legal question'. Article 96(b) UN Charter additionally grants that possibility to 'other organs of the United Nations and specialized agencies' if authorized by the UN General Assembly, provided they request clarification on legal questions 'arising within the scope of their activities'. The ICJ thus has the opportunity and competence to provide legal guidance to the UN, and consequently to strengthen the rule of law in the activities of the organization. Although they are not legally binding, advisory opinions enjoy a high degree of authority due to the Court's standing. However, they have also caused some controversy in the past, when an issue was perceived to be contentious and the advisory proceedings were seen as a 'back door' in order to circumvent the lack of jurisdiction. So far, the ICJ has rendered 27 advisory opinions on a diversity of issues ranging from the accession of Member States to the UN and the legality of the threat or use of nuclear weapons to the construction of a wall in the Occupied Palestinian Territory and the unilateral declaration of independence by Kosovo. Advisory proceedings are also foreseen in the ITLOS, either by the Seabed Disputes Chamber ${ }^{285}$ or by the Tribunal, if this is provided for in an international agreement. ${ }^{286}$ The Seabed Disputes Chamber delivered an advisory opinion on 1 February $2011,{ }^{287}$ and the Tribunal received its first request for an advisory opinion on 28 March 2013 from the Sub-Regional Fisheries Commission. ${ }^{288}$

Second, under Article 218(11) TFEU, the European Parliament, the Council of the EU, the European Commission or an EU Member State may obtain the Opinion of the ECJ as to whether an envisaged international agreement is compatible with the provisions of the TEU and the TFEU. That provision has the aim of 'forestalling complications which would result from legal disputes concerning the compatibility with the Treaties of international agreements binding upon the EU' ${ }^{289}$ Where the opinion of the Court is adverse, the international agreement envisaged may not enter into force unless it is amended or the Treaties are revised. Furthermore, pursuant to $267 \mathrm{TFEU}$, the ECJ has jurisdiction to give preliminary rulings concerning the interpretation of the Treaties and of acts of the various Union institutions, bodies, offices, or agencies. That mechanism aims to avoid divergences in the interpretation of EU law by national courts. Article 267 TFEU confers on national courts the power and, in certain circumstances, an obligation, to make a reference to the ECJ once the national court considers that a case pending before it raises issues involving an interpretation or assessment of the validity of provisions of EU law. ${ }^{290}$ The ECJ has emphasized that the system established by Article 267 TFEU with a view to ensuring that EU law is interpreted uniformly throughout the Member States establishes direct cooperation between the ECJ and the national courts by means of a procedure that is completely independent of any initiative by the parties. In that regard, the system of references for a preliminary ruling is based on a dialogue between one court and another, the initiation of

\footnotetext{
${ }^{284}$ See also Cançado Trindade (n 23).

${ }^{285}$ Art 191 UNCLOS.

${ }^{286}$ Art 21 UNCLOS; art 138 ITLOS Rules of the Tribunal.

287 ITLOS Seabed Disputes Chamber, Responsibilities and obligations of States sponsoring persons and entities with respect to activities in the Area (no 17) (Request for Advisory Opinion submitted to the Seabed Disputes Chamber) (Advisory Opinion of 1 February 2011, ITLOS Reports 2011.

${ }^{288}$ ITLOS, Request for an advisory opinion submitted by the Sub-Regional Fisheries Commission (SRFC) (no 21). The progress of the proceedings can be followed on <www.itlos.org/en/affaires/role-des-affaires/affaire-no-21/>.

${ }^{289}$ See ECJ, Opinion 2/13, Accession of the EU to the ECHR, para 145.

${ }^{290}$ See ECJ, judgment in Kelly, C-104/10, EU:C:2011:506, paras 60-61.
} 
which depends entirely on the national court's assessment as to whether a reference is appropriate and necessary. ${ }^{291}$

The clarification of international law goes hand in hand with its development. Whereas some scholars have identified law-making as one of the functions of international courts and tribunals, ${ }^{292}$ others do not go that far. ${ }^{293}$ But even without crossing the threshold to actual lawmaking, courts can 'thicken'294 international law by creating a body of precedents that impacts not only on subsequent judicial decisions but also on political discussions about the content and scope of the law. The ICJ, for example, although generally considered to be one of the more restrained courts, has created a body of case law that has shaped and developed international law far beyond the scope of the disputes that were actually submitted to it. ${ }^{295}$ Couvreur refers by way of example to the ICJ's decisions on the Vienna Convention on the Law of Treaties. ${ }^{296}$ Other authors similarly highlight the various ways in which international courts and tribunals have shaped international law, starting with the considerable contributions of the IUSCT to the rules of international arbitration and the issues of nationality, attribution and expropriation in international law, as well as the ITLOS with its case law on functional protection, precise allocation of damages, the protection of procedural rights in environmental cases and the delimitation of the continental shelf beyond 200 nautical miles. With regard to the CJEU, Lenaerts states that it 'had to create new norms that would supplement and complete the legal order established by the Treaty, aligning it with both public international law and the fundamental constitutional tenets common to its Member States' in order to ensure the legitimacy of the EU legal order. ${ }^{297}$ Finally, the ECtHR considers the ECHR as a 'living instrument' and applies an evolutive interpretation, aiming to render its rights 'practical and effective'. ${ }^{298}$

Critics who measure the contribution of the international judiciary to the rule of law only based on the number and the nature of the disputes they settled overlook that the courts' impact transcends the individual case and affects the international legal order as a whole. Despite the fact that judgments are binding only inter partes, and despite the lack of a rule of precedent in international law, judicial decisions contribute to shaping the standards of the entire international legal system. ${ }^{299}$ The importance that lies in the clarification and development of international law for the promotion of the rule of law must not be underestimated.

\section{CONCLUSION}

The past two and a half decades have seen an unprecedented multiplication of international adjudicative bodies, which enjoy increasing powers and deal with an ever-growing number of cases. Despite concerns about the possible negative consequences for the unity of international law, this development has to be welcomed from a rule of law perspective. International courts and tribunals settle disputes peacefully by legal means, assess the compliance of public power with international legal constraints, tackle impunity and contribute to the clarification and

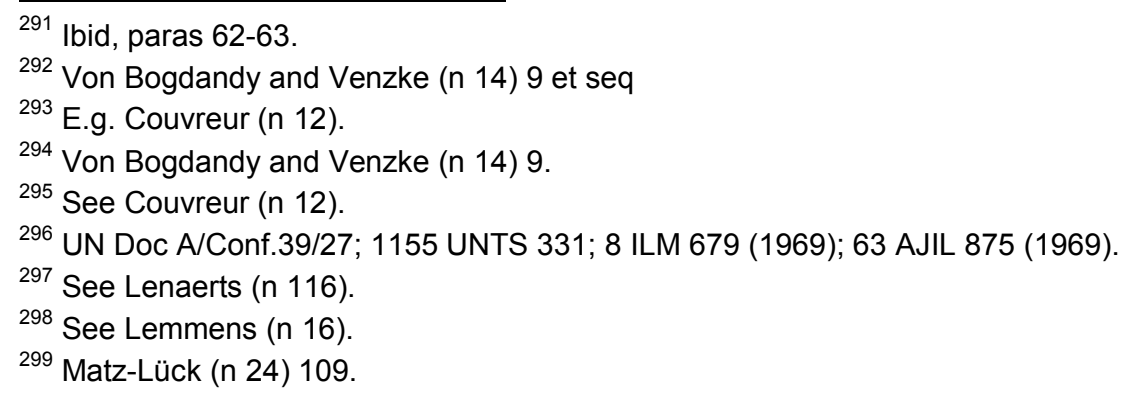


development of international law. All of their functions are aimed towards promoting and strengthening the rule of law.

While there can therefore be no doubt about the important contribution of the international judiciary to the rule of law, attention needs to be drawn to the remaining challenges.

The multiplication of international tribunals has widened the range of possibilities for states to settle their disputes peacefully by legal means, to obtain legitimation through compliance assessment by an independent body, and to combat impunity for the most serious crimes. This, and the significant contributions of every individual court and tribunal, are to be welcomed from a rule of law perspective. However, the unstructured and non-hierarchical growth of the international judicial system has also raised concerns with regard to the potential impact on the coherence of international law. ${ }^{300}$ Scholars and practitioners fear that the fragmentation of the institutional framework might translate into a fragmentation of the legal framework. Competing jurisdictions, parallel proceedings, conflicting decisions and forum shopping might threaten not only the rule of law and the legitimacy of the international legal order but risk that the very essence of a normative system of law will be lost'. ${ }^{301}$ These concerns abounded particularly in the late 1990s and early 2000s, when they were prominently taken up by two successive ICJ presidents and triggered a wealth of scholarship. Today, it can be stated that these potential problems largely did not materialize. ${ }^{302}$ In fact, open contradictions in the case law of different international courts - as often illustrated with the saga of the Nicaragua, Tadic and Genocide cases - have remained a rare exception. ${ }^{303}$ This corresponds to the observation already made by Charney in the late 1990s, that in the "core areas of international law, the different international tribunals of the late twentieth century do share relatively coherent views' ${ }^{304}$ An important role in the avoidance of conflicts between the various tribunals can be attributed to the emergence of a transnational judicial dialogue - between international courts and tribunals and between international and domestic courts. ${ }^{305}$ Indeed, Brown has argued that there is an increasing commonality in the practice of international courts to the application of rules concerning issues of procedure and remedies, and that this represents the emergence of a common law of international adjudication. This suggests that international courts can develop common approaches to the challenges that they face in the age of proliferation. It also suggests that international courts do not generally operate as self-contained regimes, but rather that they

\footnotetext{
${ }^{300}$ On the risks for the integrity of international law see for example Luis Barrionuevo Arrévalo, 'The Multiplication of International Jurisdictions and the Integrity of International Law' (2008) 15 ILSA Journal of International and Comparative Law 49, 53 et seq. See also Follesdal (n 4).

${ }^{301}$ Charney (n 23) 699.

${ }^{302}$ See also Cançado Trindade (n 23). See also the ILC Report on Fragmentation, United Nations, Fragmentation of International Law: Difficulties Arising from the Diversification and Expansion of International Law, Report of the Study Group of the International Law Commission (2006) UN Doc A/CN.4/L.682.

${ }^{303}$ Pierre-Marie Dupuy and Jorge E Viñuales, 'The Challenge of "Proliferation": An Anatomy of the Debate' in Cesare PR Romano, Karen Alter and Yuval Shany (eds) The Oxford Handbook of International Adjudication (OUP 2014) 135, 146.

${ }^{304}$ Charney (n 23) 699.

305 See Cançado Trindade (n 23); Anne-Marie Slaughter, 'Judicial Globalization' (2000) 40 Virginia Journal of International Law 1103; Francis G Jacobs, 'Judicial Dialogue and the Cross-Fertilization of Legal Systems: The European Court of Justice' (2003) 38 Texas International Law Journal 547; Yonatan Lupu and Erik Voeten, 'Precedent in International Courts: A Network Analysis of Case Citations by the European Court of Human Rights' (2011) 42 British Journal of Political Science 413; Marc Jacob, 'Precedents: Lawmaking Through International Adjudication' (2011) 12 German Law Journal 1005; Anthony Arnull, 'Judicial Dialogue in the European Union', in: Julie Dickson and Pavlos Eleftheriadis (eds) Philosophical Foundations of European Union Law (OUP 2012) 109.
} 
regard themselves as forming part of a community of international courts, which has positive implications for the development of the international legal system. ${ }^{306}$ Furthermore, although international law does not have rules on precedent or stare decisis, courts tend to rely on their own prior decisions and have frequently adopted a deferential approach to decisions rendered by other institutions. The judgments and advisory opinions of the ICJ notably enjoy a high degree of authority and are often cited in the case law of other tribunals. Consequently, the fragmentation of international law through international adjudication causes less alarm today than it did two decades ago. Nevertheless, frictions remain and need to be addressed. Some have argued for the creation of an international 'supreme court' or urged the ICJ to take up this role. However, this solution appears not only politically and practically unfeasible, but it would also take away the benefits of an international judiciary with many voices, areas of expertise and backgrounds. ${ }^{307}$ Instead, it is the task of every single international judge to recognize his role in the wider system and realize the responsibility that this entails. Today, judicial dialogue is still ad hoc and unpredictable, and rather unevenly exercised across the range of judicial bodies. The ICJ, for example, remains a relatively self-contained body, which rarely relies on decisions other than its own. In sum, judges cannot live in 'splendid isolation' ${ }^{308}$ but must be aware of the competences and case law of other institutions and maintain an open dialogue. ${ }^{309}$ Courts and tribunals need to enter into such an open dialogue with their international, supranational and domestic counterparts in order to avoid the potential negative facets of the institutional mosaic, in particular concerning competing jurisdictions and conflicting decisions. This dialogue can be informal, particularly through reference and deference to the decisions of other courts and tribunals, but it can also be formalized through regular visits and exchanges between the different courts.

A second point of concern - and a 'more disturbing element' to some $\mathrm{e}^{310}$ - is the institutional design of most international courts, which continues to rely on state consent in order to establish jurisdiction. While compulsory jurisdiction is exercised by a number of courts, many important courts, including the ICJ, do not figure among them. This lack of compulsory jurisdiction has received considerably less attention than the issue of fragmentation, although its negative impact on the rule of law is arguably far more severe. A system in which all levels of public power are equally subjected to legal constraints does not square with a judicial system that can fulfil its functions only upon the agreement of the parties. Compulsory jurisdiction is in need of strengthening at the international level and reforms for those international courts and tribunals that still operate on a voluntary basis ought to be considered as a matter of urgency. At the same time, the capacities of the international adjudicative bodies must be enhanced through adequate financing and staffing, thereby allowing the international judiciary to maintain reasonably short timeframes for their proceedings while also respecting aspects of procedural fairness.

Lastly, the expanding caseload of international courts and tribunals is both a blessing and a curse. While on the one hand the increased recourse to adjudicative bodies strengthens the rule of law, it also creates capacity problems for the judiciary. Short on resources and staff, many courts face a considerable backlog of pending cases, leading to increasingly long trials. In line with the maxim 'justice delayed is justice denied', this situation weakens the rule of law. Several courts and tribunals have recognized the need for action and have taken measures, ranging

\footnotetext{
${ }^{306}$ Brown (n 23).

${ }^{307}$ See Charney (n 23) 698.

${ }^{308}$ Linton and Tiba (n 24) 418.

${ }^{309}$ Buergenthal (n 21) 274.

${ }^{310}$ Higgins (n 23).
} 
from 'practice directions' for parties and judges at the $\mathrm{ICJ}^{311}$ to the increased use of the singlejudge procedure at the ECtHR. ${ }^{312}$ While these steps may be successful in reducing the backlog, they can also have negative effects on courts' procedural fairness and consequently on the rule of law. The ECtHR, for example, managed to reduce the number of cases on its docket from more than 160000 in 2011 to less than 100000 in $2014 .{ }^{313}$ This significant decrease was largely due to the strong reliance on the new competence of single judges to declare cases inadmissible 'where such a decision can be taken without further examination'. ${ }^{314}$ Single judge decisions are not only not published, they are also 'no longer than a one-page letter stating the formal ground for rejection without further reasoning or argumentation'. ${ }^{315}$ There can be considerable doubts on the fairness of a judicial procedure that in many cases makes it difficult for the applicant to understand the grounds on which the decision was taken and severely limits the possibility for internal and external control. Not only will the authority of such a decision be weaker, it may also negatively impact on the legitimacy of the court or tribunal, which should strive to reconcile efficiency with procedural fairness. Only if both factors are ensured can the judiciary effectively contribute to the rule of law.

Finding answers to these challenges will be essential for the further strengthening of the international judiciary's contribution to the rule of law.

What is more, international courts and tribunals are by no means a panacea for all the problems facing the international community. As Lon Fuller put it: 'the most we can expect of constitutions and courts is that they save us from the abyss; they cannot be expected to lay out very many compulsory steps toward truly significant accomplishment' ${ }^{316}$ Furthermore, notwithstanding the crucial role of adjudication in the international legal order, judicial settlement may have unintended effects on the development of the law. Notably, there exists a tension between the retrospective analysis of the rights and duties of states involved in litigation needed for the settlement of disputes on the one hand, and the prospective effect of the principles emerging from the judicial decision that may govern future conduct on the other hand. The absence of an international legislature implies that judicial pronouncements are not easily overturned, and a judicial decision may prematurely restrict the development of the law in areas that are in flux. ${ }^{317}$ Finally, bringing issues such as the permissibility of the killing of innocents by nuclear weapons within the realm of judicial reasoning may detract from the relevant moral standard and leave the prohibition in a weakened state. ${ }^{318}$

\footnotetext{
${ }^{311}$ See Couvreur (n 12).

312 See Lemmens (n 16).

313 ECHR, Press conference President Dean Spielmann 30 January 2014,

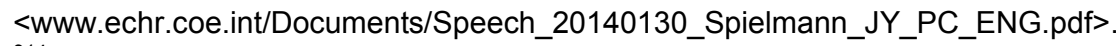

${ }^{314}$ Art 27ECHR.

315 Janneke Gerards, 'Inadmissibility Decisions of the European Court of Human Rights: A Critique of the Lack of Reasoning' (2014) Human Rights Law Review 1, 6.

${ }^{316}$ Fuller ( $n$ 85) 44. See the similar sentiment expressed by Secretary-General Dag Hammarskjöld with respect to the UN: 'It has been said that the United Nations was not created in order to bring us heaven, but in order to save us from hell. I think that sums up as well as anything I have heard both the essential role of the United Nations and the attitude of mind that we should bring to its support': United Nations, Address by Secretary-General Dag Hammarskjöld at University of California Convocation, Berkeley, California, Thursday, May 13, 1954, at 10:00 A.M. (Pacific Coast Time) (UN Doc SG/382).

317 See Lowe (n 111) 209-222.

${ }^{318}$ Koskenniemi (n 36) 140, 152-153 and 161, arguing that the ICJ should not have been asked the question of the permissibility of nuclear weapons in Legality of the Threat or Use of Nuclear Weapons (n 36), and that the Court's silence was beneficial 'inasmuch as it, and it only, could leave room for the workings of the moral impulse, the irrational non-foundational appeal against the killing of the innocent' (at 153).
} 
The imperfect but important contribution of international courts consists in convincing other actors in international law of a more rigorous application of the rule of law at all levels. That arguably implies making international law 'a better example of a legal system,, ${ }^{319}$ thereby conforming to a greater extent with what may be the real purpose of international law and of the rule of law in the international realm: not the protection of sovereign states, but the protection of the populations committed to their charge. ${ }^{320}$ States are indeed not ends in themselves, but instruments for the well-being of human individuals, who are ends in themselves. ${ }^{321}$ International and supranational courts infuse predictability and security in the international legal order, creating space for the liberty of individuals and groups. Such liberty as independence from the power of others, including public authorities, can only be realized by that form of moral association called 'the rule of law'. ${ }^{322}$

\footnotetext{
${ }^{319}$ Waldron (n 141) 46-7. See also Simmonds (n 114) 5, 46, 99, proposing an archetypal concept of law: to count as 'law', a regime or system must approximate to the archetype to some degree. That archetype can be reached to varying degrees, which implies that it also serves as a guiding ideal 'to which legal systems ought to strive to conform more closely', and social practices therefore 'count as instances of law only when they partially embody an idea that they can never fully realize'; see also Rawls (n 113) 207, arguing that the precepts of justice associated with the rule of law 'are those that would be followed by any system of rules which perfectly embodied the idea of a legal system'; and Kelsen (n 144) ix, describing the approach to the aim of world peace as 'one of slow and steady perfection of the international legal order'.

${ }^{320}$ See Koskenniemi (n 36) 145, suggesting that arguably 'the law's purpose is to protect the innocent', adding that 'it is hard to see a more basic purpose for it in a system that excludes reference to personal virtue'.

${ }^{321}$ Waldron (n 112) 24 building on Immanuel Kant, Groundwork of the Metaphysics of Morals (Mary Gregor (ed) CUP 1785/1999) 78-79.

${ }^{322}$ Simmonds ( $\mathrm{n} 114$ ) 152, describing it as 'a common good that is intrinsic to law's nature'. See also De Baere (n 83) 382-383, with respect to the rule of law as the cornerstone of European integration.
} 


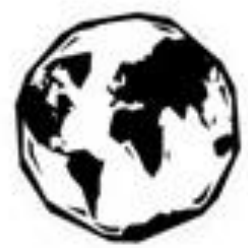

Institute for International Law

The Leuven Centre for Global Governance Studies is an interdisciplinary research centre of the Humanities and Social Sciences recognized as a Centre of Excellence at the KU Leuven. It hosts researchers from law, economics, political science, history, philosophy and area studies. The Centre initiates and conducts interdisciplinary research on topics related to globalization, governance processes and multilateralism, with a particular focus on the following areas: (i) the European Union and global governance; (ii) human rights, democracy and rule of law; (iii) trade and sustainable development; (iv) peace and security; (v) global commons and outer space; (vi) federalism and multi-level governance; (vii) non-state actors and emerging powers. It hosts the InBev Baillet-Latour Chair EU-China and the Leuven India Focus.

In addition to its fundamental research activities the Centre carries out independent applied research and offers innovative policy advice and solutions to policy-makers.

In full recognition of the complex issues involved, the Centre approaches global governance from a multi-level and multi-actor perspective. The multi-level governance perspective takes the interactions between the various levels of governance (international, European, national, subnational, local) into account, with a particular emphasis on the multifaceted interactions between the United Nations System, the World Trade Organization, the European Union and other regional organizations/actors in global multilateral governance. The multi-actors perspective pertains to the roles and interactions of various actors at different governance levels, which includes public authorities, formal and informal international institutions, business enterprises and non-governmental organizations.

For more information, please visit the website www.globalgovernancestudies.eu

Leuven Centre for Global Governance Studies

Huis De Dorlodot, Deberiotstraat 34, 3000 Leuven, Belgium

Tel. ++3216328725

Fax ++3216373547

info@ggs.kuleuven.be

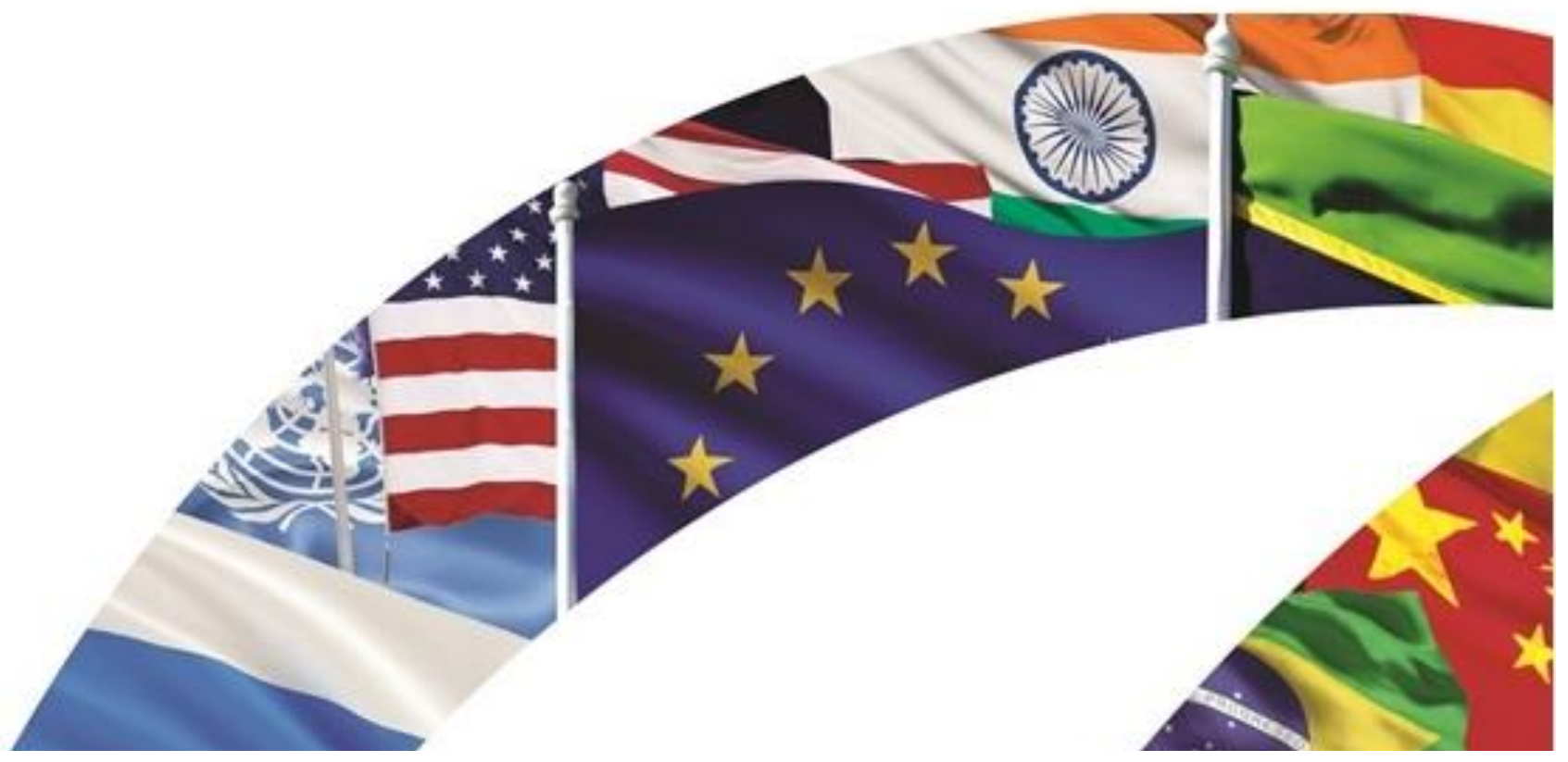

